\title{
Neurogenic Inflammation: One of the Participants of Migraine and the Contribution of Translational Research
}

\author{
Eleonóra Spekker ${ }^{1}$, Masaru Tanaka ${ }^{1,2}$, Ágnes Szabó ${ }^{2}$ and László Vécsei 1,2,*
}

1 MTA-SZTE, Neuroscience Research Group, H-6725 Szeged, Hungary; spekker.elenora@med.u-szeged.hu (E.S.); tanaka.masaru.1@med.u-szeged.hu (M.T.)

2 Department of Neurology, Interdisciplinary Excellence Centre, Albert Szent-Györgyi Medical School, University of Szeged, H-6725 Szeged, Hungary; szabo.agnes.4@med.u-szeged.hu (Á.S.)

* Correspondence: vecsei.laszlo@med.u-szeged.hu; Tel.: +36-62-545-351; Fax: +36-62-545-597

\begin{abstract}
Migraine is a primary headache disorder characterized by unilateral throbbing, pulsing headache, which lasts for hours to days, and the pain can interfere with daily activities. It exhibits various symptoms, such as nausea, vomiting, sensitivity to light, sound, and odors and physical activity consistently contributes to worsening pain. Despite the intensive research, little is still known about the pathomechanism of migraine. It is widely accepted that migraine involves activation and sensitization of the trigeminovascular system. It leads to the release of several proinflammatory neuropeptides and neurotransmitters and causes a cascade of inflammatory tissue responses including vasodilation, plasma extravasation secondary to capillary leakage, edema, and mast cell degranulation. Convincing evidence obtained in rodent models suggests that neurogenic inflammation is assumed to contribute to the development of a migraine attack. Chemical stimulation of the dura mater triggers activation and sensitization of the trigeminal system and causes numerous molecular and behavioral changes; therefore, this is a relevant animal model of acute migraine. This review article discusses the emerging evidence supporting the involvement of neurogenic inflammation and neuropeptides in the pathophysiology of migraine, presenting the most recent advances in preclinical research and the novel therapeutic approaches to the disease.
\end{abstract}

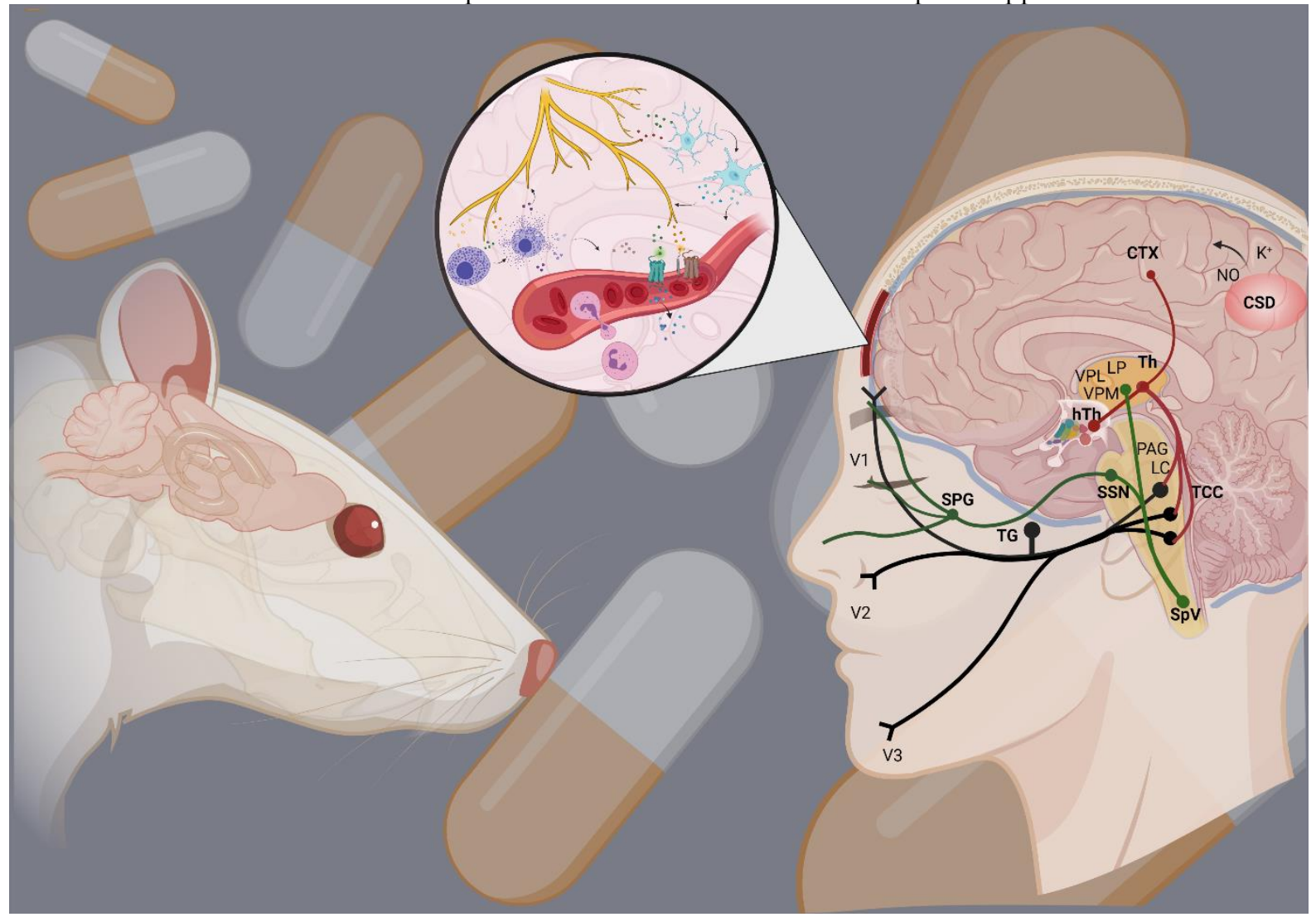

Graphical abstract 
Keywords: primary headache, migraine; trigeminal system; neuropeptides; neurogenic inflammation; animal model; inflammatory soup; dura mater; immune system; migraine treatment

\section{Introduction}

Migraine is a common neurological condition, being the third most prevalent disease worldwide [1]. According to the Global Burden of Disease Study 2016, migraine is the second leading cause of disability [2]. The prevalence of migraine is $14.7 \%$ and it is three times more common in women than men; in addition, women are less responsive to treatment [3]. Moreover, as migraine is a chronic episodic disorder that predominantly affects the working sector of a population and thus, it has high social costs [4]. Migraine is ascribed to complicated, multifactorial conditions that give rise to substantial variations among patients and single patient responses to treatments [5]. Clinically, migraine can cause a variety of symptoms besides recurrent headaches, such as allodynia, photo- and phonophobia, and decreased daily activity, which can last from 4 to 72 hours without treatment [6]. Due to its own pathogenesis and the fact that no other cause can be associated with the development of the disease, migraine belongs to the family of primary headache disorders [7].

The clinical course of migraine can be divided into different stages: the prodrome phase, a possible aura, followed by the headache and the recovery stage (postdrome). The prodrome phase typically occurs up to a few days before the headache attack, changes in well-being and behavior are experienced, fatigue and impaired concentration occur as frequent complaints [8]. In $25 \%$ of the migraineurs a temporary dysfunction of the central nervous system - the aura phenomenon - occurs [9]. The most common symptoms are visual (e.g. visual field disturbances) but sensory or speech disturbances and rarely motor symptoms can be also observed [6,10.11.12]. The typical aura is appearing before or at the beginning of the headache and lasts up to one hour. The headache in migraineurs is moderate or strong and throbbing, lasting 4-72 hours and associated with sensitivity to light/sound and nausea/vomiting. Physical activity worsens the symptoms and thus, the migraineurs seek rest (Figure 1A). 

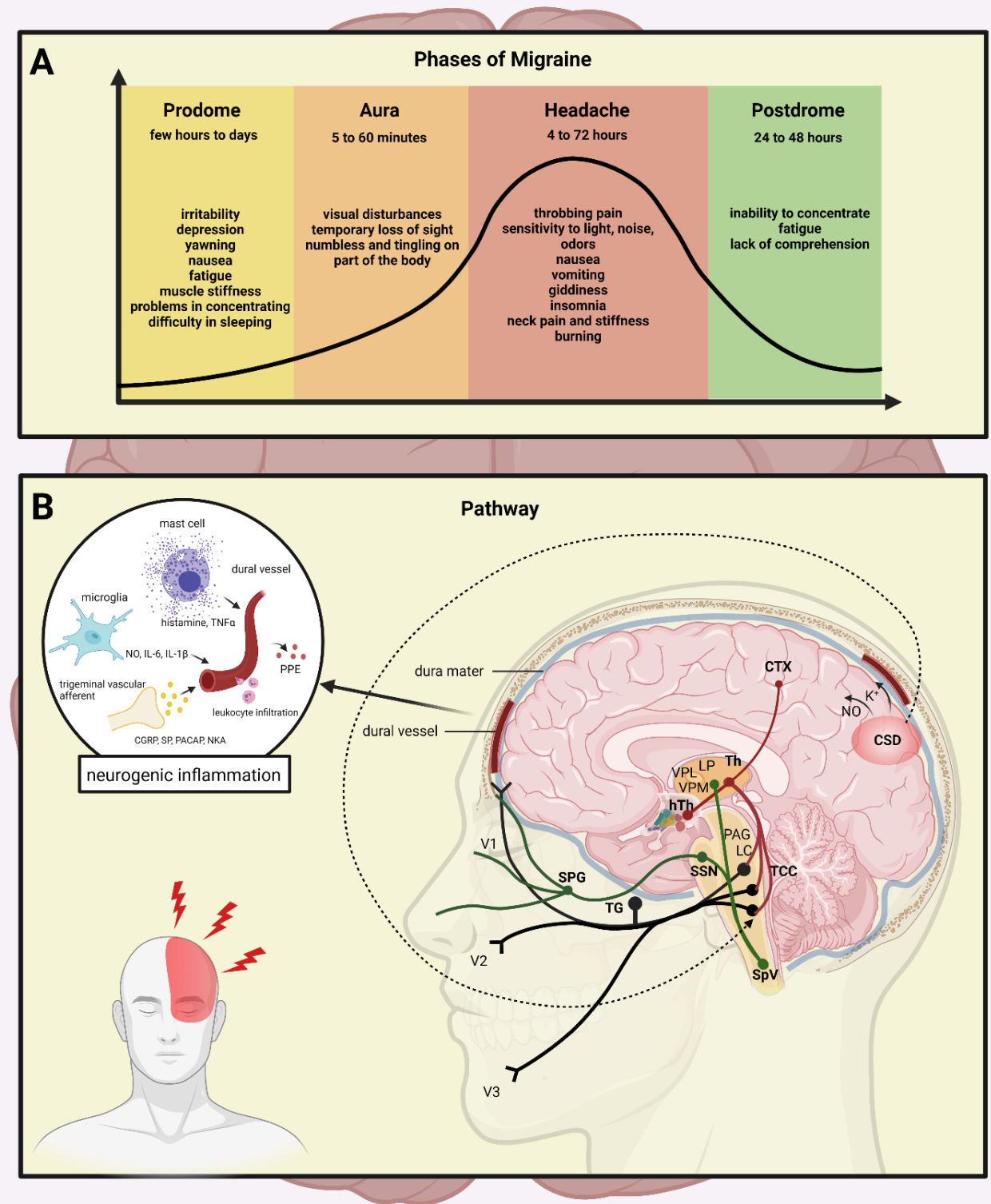

Figure 1. The stages and the pathways of migraine. A: The stages of migraine attack the prodrome phase, a possible aura, followed by the headache and subsequently the postdrome. A strong headache is frequently accompanied with nausea, vomiting, and sensitivity to light, which last 4 to 72 hours. B: Mechanisms and structures involved in the pathogenesis of migraine. CTX: cortex, NO: nitric-oxide, CSD: cortical spreading depression, Th: thalamus, hTh: hypothalamus, LP: lateral posterior nucleus, VPM: ventral posteromedial nucleus, VPL: ventral posterolateral nucleus, PAG: periaqueductal grey matter, LC: locus coeruleus, TCC: trigeminocervical complex, SSN: superior salivatory nucleus, SpV: spinal trigeminal nucleus caudalis, TG: trigeminal ganglion, SPG: sphenopalatine ganglion, V1: ophthalmic nerve, V2: maxillary nerve, V3: mandibular nerve, CGRP: calcitonin gene-related peptide, SP: substance P, PACAP: pituitary adenylate cyclase-activating polypeptide, NKA: neurokinin A, PPE: plasma protein extravasation, TNF $\alpha$ : tumour necrosis factor alpha, IL: interleukin

Despite intensive research, the pathomechanism of migraine is still unclear, however, activation and sensitization of the trigeminal system (TS) is essential during the attacks [13]. The TS is responsible for processing painful stimuli from the cortical area; during its activation, neurotransmitters, such as calcitonin gene-related peptide (CGRP), substance $\mathrm{P}(\mathrm{SP})$, pituitary adenylate cyclase-activating polypeptide (PACAP), and neurokinin A (NKA) are released both at the peripheral and central arm of the primary sensory neurons [14]. The neuropeptide release can induce mast cell degranulation and plasma extravasation leading to neurogenic inflammation (NI) [15]. In the meantime, activation of the second-order neurons occurs in the caudal trigeminal nucleus (TNC) and their 
axons ascend to terminate in the thalamus, and the nociceptive information is projected to the primary somatosensory cortex [16]. Recent neuroimaging studies revealed other regions of the central nervous system (CNS) (e.g. cerebellum, insula, pulvinar) that might play a role in the modulation of pain sensation [17, 18] (Figure 1B).

In the 1950s, Ray and Wolff developed the first theory about the pathomechanism of migraine. They believed that migraine pain was caused by extracranial vasodilation, while intracranial vasospasm was responsible for aura symptoms [19]. At that time this theory was in line with the pharmacological observations that the potent vasodilatator amyl nitrate aborted the aura phase, meanwhile ergotamine with vasoconstrictive properties decreased the headache [20]. Since vascular changes do not explain all the symptoms experienced during migraine attacks new theories emerged regarding the pathomechanism of migraine.

The most widely accepted theory is focusing on the so-called cortical spreading depression (CSD) first described by Leao and Morison [21], which may be the equivalent of the aura phenomenon [22] playing a role in the development of migraine attacks [23]. During CSD, depolarization following an excitatory wave across the cerebral cortex changes cerebral blood supply, increases tissue metabolism, releases amino acids and nitric oxide in the cortex, which activates nerves running in the dura, thus dilating the dural vessels, leading to sterile inflammation [24]. Under experimental conditions, CSD can activate secondary trigeminal nociceptors [25], suggesting that susceptibility to CSD might be responsible for the appearance of the attack.

Weiller and colleagues observed that the dorsolateral pons and the dorsal midbrain involving the nuclei nucleus raphe magnus (NRM), nucleus raphe dorsalis (DR), locus coeruleus (LC), and the periaqueductal grey matter (PAG) are activated during a migraine attack, which persists even after triptan treatment [26]. These nuclei can influence TNC activity and they are involved in the transmission of pain. Brainstem serotonergic (NRM and PAG) and adrenergic (LC) nuclei contribute to the activation of the trigeminovascular system [27]. These brainstem areas - in addition to the trigeminovascular system - have a bidirectional connection with thalamus and hypothalamus. The thalamus has a role in integrating nociceptive inputs in migraine and pain sensation. The hypothalamus has direct connections with many structures involved in pain processing, including the nucleus tractus solitarius, rostral ventromedial medulla, PAG, and NRM [28, 29, 30]. It is hypothesized that the altered function of these brainstem migraine generators also play a major role in attack development.

Nowadays, the most accepted concept is that migraine is a neurovascular disorder, which originates in the CNS, causing hypersensitivity to the peripheral trigeminal nerve fibers that innervate the vessels of the meninges.

This review article discusses the processes underlying the pathomechanism of migraine, focussing on the role of neuropeptides and neurogenic inflammation. Furthermore, it emphasizes the importance of preclinical translational research which has led to current understanding of migraine and summarizes the novel potential therapeutic options for migraine.

\section{Dura mater in migraine}

The dura mater, its vasculature supply, and the cerebral blood vessels are the only structures containing nociceptive nerve fibers [31]. The role of dura mater in migraine pain was widely examined. Ray and Wolff found that electrical stimulation of dural and cerebral vessels can cause nausea and the perception of headache-like pain in humans [19]. The dura mater is the outermost layer of the meninges and is located directly underneath the skull and vertebral column bones. The three branches of the trigeminal nerve (ophthalmic (V1), maxillary (V2), and mandibular (V3)) innervate the face and head region [32]. Dowgjallo and Grzybowski were the first to find the origin of meningeal nerve fibers in the trigeminal ganglion (TG) [33, 34]. The tentorial nerve (a branch of the ophthalmic nerve) innervates most of the supratentorial dura; this nerve supplies the falx cerebri, calvarial dura, and superior surface of the tentorium cerebelli; forming a dense 
plexus with the arteries that form the vascular intracranial pain-sensitive structures [35]. The afferents innervating intracranial structures are collectively referred to as the trigeminovascular system [36, 37]. Strassmann described that peripheral trigeminovascular neurons become mechanically hypersensitive to dural stimulation, which explains the pulsation and intensification of headache in case of cough or bending [38]. Furthermore, Burstein et al. observed that stimulation of the dura causes prolonged sensitization of central trigeminovascular neurons in the spinal trigeminal nucleus [39]. Several studies have shown peptidergic trigeminal afferents to innervate the dura mater $[40,41,42]$.

\section{Neuropeptides and neurotransmitters}

Meningeal nerve fibers are immunoreactive for CGRP, SP, NKA, neuropeptide $Y$ (NPY), and vasoactive intestinal peptide (VIP), among others [43]. CGRP plays multiple roles in neurogenic inflammation [44]. In pharmacological and immunological experiments, antagonism of CGRP supported, that CGRP is indirectly involved in plasma extravasation which is primarily caused by SP and NKA [45]. Together with SP, CGRP can trigger mast cell degranulation to release proinflammatory and inflammatory compounds [46]. Beside these, dural mast cells and satellite glia express the CGRP receptor [47]. It is suggested that satellite glia and neurons are involved in a positive feedback loop of CGRP synthesis and release, maintaining increased inflammation and sensitization [48].

SP is widely distributed in the central and peripheral nervous systems of vertebrates [49]. In the CNS, it is present in the dorsal root ganglion, spinal cord, hippocampus, cortex, basal ganglia, hypothalamus, amygdala, and TNC $[50,51]$ and has a role in the neurotransmission of pain and noxious stimuli in the spinal cord [52]. It has been described in numerous cell type product SP, e.g. macrophages, eosinophils, lymphocytes, and dendritic cells [53,54]. The SP-induced release of inflammatory mediators such as cytokines, oxygen radicals, and histamine enhances tissue damage and stimulates further recruitment of leukocytes, thereby enhancing the inflammatory response [55]. SP induces local vasodilation and changes the vascular permeability, thereby increasing the delivery and accumulation of leukocytes into tissues to express local immune responses [56]. SP often co-express with other transmitter molecules, like CGRP and glutamate in the trigeminal ganglion and trigeminal nucleus caudalis $[57,58]$. During the headache phase of migraine, a significant increase in plasma SP and CGRP levels is demonstrated [59].

Moreover, PACAP is found in several structures that are relevant to the pathomechanism of migraine, e.g. in the dura mater, the cerebral vessels [60], the TG [61], the TNC [62] and cervical spinal cord [63]. It was recently found that PACAP is coexpressed with CGRP in some dural nerve fibers [64]. PACAP plays a role in neuromodulation, neurogenic inflammation, and nociception [65], and in addition, it is involved in the higher-order processing of pain in brain regions such as the thalamus and amygdala $[66,67]$. PACAP is also relevant in the central sensitization and emotional load of pain [68]. Zhang and colleagues found that following inflammation in sensory neurons, PACAP is upregulated [69]. Meningeal sensory fibers can release neuropeptides from their peripheral endings in the meninges, where they can evoke components of neurogenic inflammation [64].

VIP is widely distributed in the central and peripheral nervous systems [70]. VIP plays as potent vasodilators, acting on the smooth muscle cells in arterioles [71]. VIP can modulate mast cell degranulation and the production of proinflammatory cytokines, such as interleukins, IL-6 and IL-8 [72]. In a clinical study, during the interictal period of chronic migraine, higher VIP levels have been reported in peripheral venous blood than in control subjects [73]. Pellesi et al. observed that as opposed to shorter vasodilation, prolonged VIP-mediated vasodilation causes more headaches [74]. Together, VIP may contribute to migraine pain through vasodilation and dural mast cell degranulation.

Transient receptor potential vanilloid-1 receptor (TRPV1), a nonselective cation channel, a molecular component of pain detection and modulation [75]. TRPV1 receptors 
are present in the human TG [76] and trigeminal afferents, which innervate the dura mater [77]. In addition to excessive heat, various exogenous and endogenous triggering factors can directly activate or sensitize TRPV1 [78]. TRPV1 activation leads to the release of neuropeptides, such as SP and CGRP which can cause vasodilation and initiate neurogenic inflammation within the meninges [79]. TRPV1 activation and/or sensitization can enhance inflammatory responses via the expression and release of other inflammatory mediators.

Histamine plays a role in migraine; it can modulate neurogenic inflammation and nociceptive sensitization [80]. During a migraine attack, elevated levels of a histamine precursor histidine were found in plasma and cerebrospinal fluid (CSF) [81], and the histamine levels of the plasma were increased both ictally and interictally in migraine patients [80]. The release of SP contributes to local vasodilatation, induces histamine release from mast cells, and produces flare and further activating other sensory nerve endings [82]. C-fibers are known to be activated by histamine and are responsible for the neuropeptide release. Nerve fibers which contain histamine, have been found in the superficial laminae of the dorsal horn, an essential site for nociceptive transmission [83]. In inflammatory conditions, histamine can mediate the release of SP and glutamate [84].

\section{Neurogenic inflammation}

The localized form of inflammation is neuroinflammation, which occurs in both the peripheral and central nervous systems. The main features of NI are the increased vascular permeability, leukocyte infiltration, glial cell activation, and increased production of inflammatory mediators such as cytokines and chemokines [83]. NI increases the permeability of the blood to the brain barrier, thus allowing an increased influx of peripheral immune cells into the central nervous system [86] (Figure 2A). 

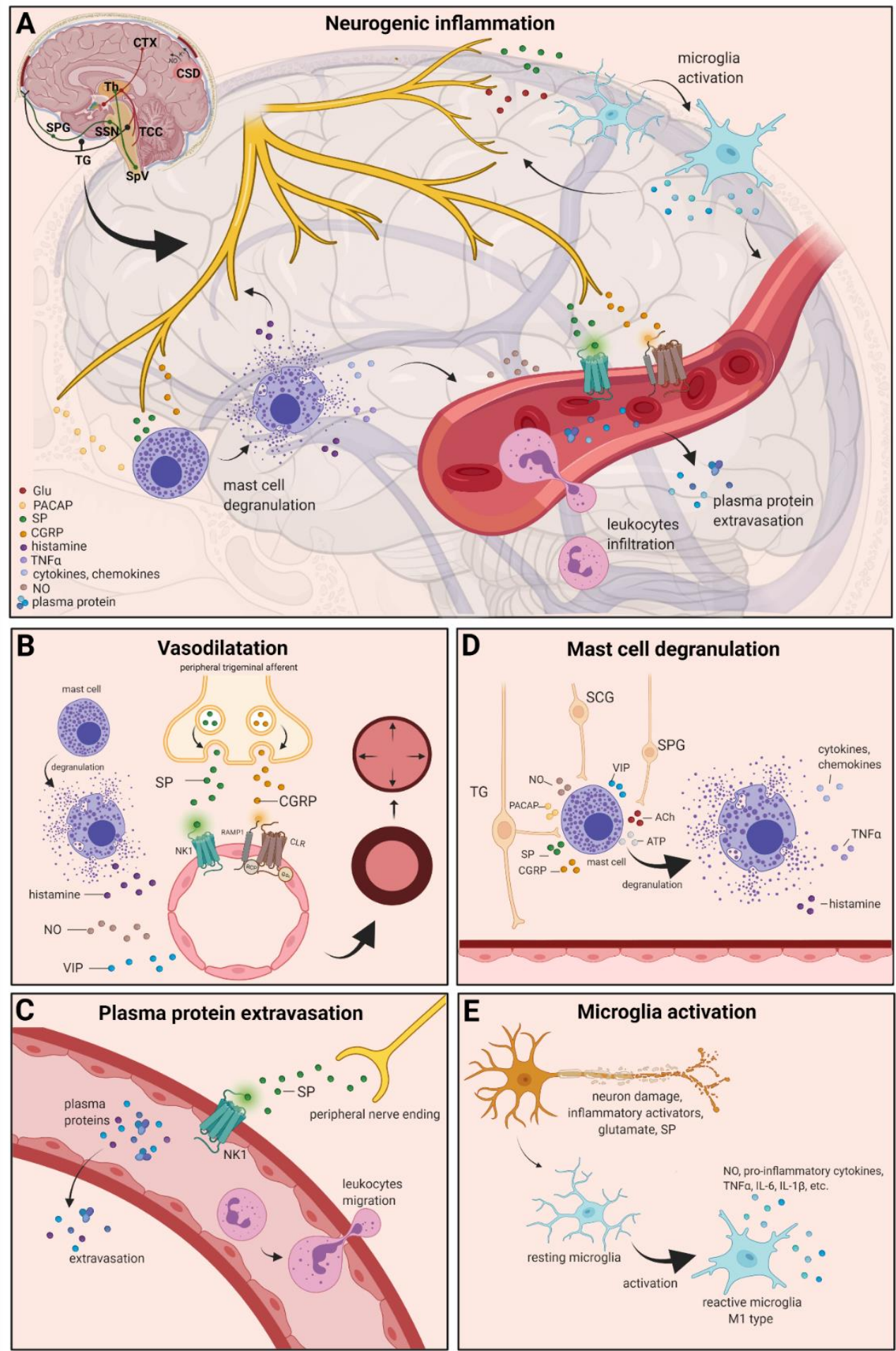

Figure 2. Neurogenic inflammation and its main features. A: Stimulation of the trigeminal nerve causes the release of neuropeptides, including CGRP, SP, NO, VIP, 5-HT, leading to neurogenic inflammation which has four main features: the increased vascular permeability, leukocyte infiltration, glial cell activation, and increased production of inflammatory mediators such as cytokines and chemokines. B: Vasoactive peptides, such as CGRP, SP are binding its receptors on smooth muscle of dural vessels and cause vasodilatation. The released neuropeptides induce mast cell degranulation which resulting in the release of histamine that leads endothelium-dependent vasodilation. C: Binding of the released SP to the NK1 receptors expressed on the microvascular blood vessels disrupts the membrane and causes plasma protein leakage and leukocyte extravasation. D: Mast cells are in close association with neurons, especially in the dura, where they can be activated following trigeminal nerve and cervical or sphenopalatine ganglion stimulation. Release of neuropeptides causes mast cell degranulation which leads to release of histamine, serotonin and selectively can cause the release of pro-inflammatory cytokines such as TNF- $\alpha$, IL-1, 
and IL-6. E: Under the influence of inflammatory stimuli, microglia can become reactive microglia. Microglia activation leads to the production of inflammatory mediators and cytotoxic mediators.

The concept of NI was introduced by the experiment of Goltz and Bayliss, in which skin vasodilation was observed during electrical stimulation of the dorsal horn, which could not be linked to the immune system [87, 88]. Dalessio was the first who hypothesized a connect ion between NI and migraine and believed that headache is a result of vasodilation of cranial vessels associated with local inflammation [89]. This theory was later reworked by Moskowitz, who believed that upon activation, the neuropeptide release from trigeminal neurons has a role in increasing vascular permeability and vasodilation [90].

There are several theories concerning the mechanism of NI. Hormonal fluctuations or cortical spreading depression can initiate two types of processes: activating the TS to trigger the liberation of neuropeptides from the peripheral trigeminal afferents and/or degranulating the mast cells that can lead to the release of neuropeptides by activating and sensitizing the nociceptors [91]. In rats Bolay and colleagues demonstrated that after local electrical stimulation of the cerebral cortex, CSD is generated and it can trigger trigeminal activation, which causes meningeal inflammation occurring after the CSD disappearance [92]. Both CGRP and SP play an important role in the development of NI. Released peptides, such as CGRP, bind to its receptor on smooth muscle cells, eliciting a vasodilatory response, thereby increasing meningeal blood flow in the dural vasculature. In contrast to CGRP, binding of the released SP to the NK1 receptors expressed on the microvascular blood vessels disrupts the membrane and causes plasma protein leakage. Both neuropeptides can induce mast cell degranulation through their specific receptors and further sensitize meningeal nociceptors [91]. The meningeal nerve fibers also contain neurotransmitters (e.g., glutamate, serotonin) and hormones (e.g., prostaglandins) that can affect the activation and release of neuropeptides causing neurogenic inflammation [89]. Moreover, several cell types (e.g.: endothelial cells, mast cells and dendritic cells) can release tumor necrosis factor alpha (TNF $\alpha$ ), interleukins, nerve-growth factor (NGF), VIP also causing plasma protein extravasation (PPE) $[93,94]$ which is a key characteristic of NI. In addition, neuronal nitric oxide synthase (nNOS) enzyme can be detected in the trigeminal nerve endings, the dural mastocytes and also the TNC and the TG [95], which catalyzes the synthesis of retrograde signaling molecule nitric oxide (NO). NO has a major role in mediating many aspects of inflammatory responses; $\mathrm{NO}$ can affect the release of various inflammatory mediators from cells participating in inflammatory responses (e.g., leukocytes, macrophages, mast cells, endothelial cells, and platelets) [96]. Through its retrograde signaling action, astrocytes can influence the release of CGRP, SP, and glutamate [97, 98]. Beside this, bradykinin and histamine induce NO release from vascular endothelial cells, suggesting a strong interaction between NO and inflammation [99]. The inflammation can lead to CGRP release from the activated primary afferent neurons, which force satellite glial cells to release NO. NO can induce nNOS, which can be considered a significant marker of the sensitization process of the trigeminal system. TRPV channels permit afferent nerves to detect thermal, mechanical, and chemical stimuli, thereby regulating NI and nociception [100]. TRPV1 was identified in dorsal root ganglion (DRG), TG neurons, and spinal and peripheral nerve terminals [101]. Inflammatory mediators remarkably up-regulate TRPV1 through activation of phospholipase $C$ (PLC) and protein kinase A (PKA) and protein kinase $C$ (PKC) signaling pathways [102, 103, 104, 105]. Increased TRPV1 expression in peripheral nociceptors contributes to maintaining inflammatory hyperalgesia [101]. In an experimental injury model, Vergnolle et al. demonstrated that a decrease in osmolarity of extracellular fluid could induce neurogenic inflammation, which TRPV4 can mediate [106]. Furthermore, plasma and cerebrospinal fluid levels of neuropeptides, histamine, proteases, and proinflammatory cytokines (e.g., TNF $\alpha$, IL-1 $\beta$ ) are elevated during migraine attacks [107, $108]$, suggesting that neuroimmune interactions contribute to migraine pathogenesis.

\subsection{Vasodilatation}


There are various cell types in blood vessels that both release and respond to numerous mediators that can contribute to migraine; this includes growth factors, cytokines, adenosine triphosphate (ATP), and NO [109, 110, 111, 112]. In the central system, NO may be involved in the regulation of cerebral blood flow and neurotransmission [113]. NO can stimulate the release of neuropeptides and causes neurogenic vasodilation [114]. In addition to NO, NGF also increases the expression of CGRP and enhances the production and release of neuropeptides, including SP and CGRP, in sensory neurons [115]. CGRP - a potent vasodilator - releases from intracranial afferents during migraine attacks. This vasodilatory effect of CGRP is mediated by its action on CGRP receptors which stimulates the adenyl cyclase and increases cyclic adenosine monophosphate (cAMP), thus producing potent vasodilatation via the direct relaxation of vascular smooth muscle [116, 117]. In response to prolonged noxious stimuli, $\mathrm{SP}$ is released from trigeminal sensory nerve fibers around dural blood vessels and leading to endothelium-dependent vasodilation [82]. VIP also contributes to neurogenic inflammation by inducing vasodilation [118] (Figure 2B).

\subsection{Plasma protein extravasation}

Another critical feature of neurogenic inflammation is PPE. Based on preclinical studies, the neurogenic PPE plays a role in the pathogenesis of migraine [119]. In several studies, following electrical stimulation of the trigeminal neurons or intravenous capsaicin, the peripheral nerve endings in the dural vasculature released SP, which caused plasma protein leakage and vasodilation through the NK-1 receptors [120]. Transduction of the SP signal through the NK1 receptor occurs via G protein signaling and the secondary messenger cAMP, ultimately leading to the regulation of ion channels, enzyme activity, and alterations in gene expression [121]. SP can indirectly influence plasma extravasation by activating mast cell degranulation, which results in histamine release [122]. In addition, NKA is able to induce plasma protein efflux and activate inflammatory cells [123] (Figure 2C).

\subsection{Mast cell degranulation}

It is well known that dural mast cells play a role in the pathophysiology of migraine [124]. Meningeal mast cells are in close association with neurons, especially in the dura, where they can be activated following trigeminal nerve and cervical or sphenopalatine ganglion stimulation [125]. The release of neuropeptides, such as CGRP, PACAP, and SP from meningeal nociceptors can cause the degranulation of mast cells [126], resulting in the release of histamine, serotonin and selectively can cause the release of proinflammatory cytokines such as TNF- $\alpha$, IL-1, and IL-6 $[127,128,129]$. The plasma and CSF levels of these mediators (e.g. CGRP, TNF $\alpha$, and IL-1 $\beta$ ) are enhanced during migraine attacks [106]. VIP promotes degranulation of mast cells [130], similar to the effects of SP [122]. It was found that CSD can induce intracranial mast cell degranulation and promote the activation of meningeal nociceptors [131, 132]. Besides these, according to several studies, mast cells can be activated by acute stress [125, 133, 134] which is known to precipitate or exacerbate migraines $[135,136]$. Based on these findings, mast cells in themselves may promote a cascade of associated inflammatory events resulting in trigeminovascular activation (Figure 2D).

\subsection{Microglia activation}

Microglia appears in the CNS and can exert neuroprotective and neurotoxic effects, too. Under the influence of inflammatory stimuli, microglia can become efficient mobile effector cells [137]. Microglia activation leads the production of inflammatory mediators and cytotoxic mediators (e.g. NO, reactive oxygen species, prostaglandins) [138, 139], which might disrupt the integrity of the blood brain barrier, thereby allowing leukocyte migration into the brain [140]. Microglia express receptors for neurotransmitters such as glutamate, gamma- aminobutyric acid, noradrenaline, purines, and dopamine [141]. It has been described that activation of ion channels is related to the activation of microglia, 
therefore neurotransmitters probably influence microglia function [142]. Glutamate leads to neuronal death but is also an activation signal for microglia [143]. Activation of glutamate receptors causes the release of TNF- $\alpha$, which with microglia-derived Fas ligand leads to neurotoxicity [144]. Besides this, Off signals from neurons appear important in maintaining tissue homeostasis and limiting microglia activity under inflammatory conditions, presumably preventing damage to intact parts of the brain [145]. Endothelin B-receptor-mediated regulation of astrocytic activation was reported to improve brain disorders such as neuropathic pain [146]. SP also directly activates microglia and astrocytes and contributes to microglial activation [147, 148], initiating signaling via the nuclear factor kappa B pathway, leading to pro-inflammatory cytokines production [149] (Figure 2E).

\subsection{Cytokines, chemokines}

Cytokines are small proteins produced by most cells in the body, which possess multiple biologic activities to promote cell-cell interaction [150]. There is evidence that cytokines play an important role in several physiological and pathological settings such as immunology, inflammation, and pain. [151]. The most important pro-inflammatory cytokines include IL-1, IL-6, and TNF $\alpha$, and the key chemokine is IL-8 [151]. Cytokines and chemokines are released by neurons, microglia, astrocytes, macrophages, and $\mathrm{T}$ cells, and these factors might activate nociceptive neurons [152]. TNF $\alpha$ can trigger tissue edema and immune cell infiltration [153] and can influence the reactivity of signal nociceptors to the brain and increase blood levels during headaches, playing a crucial role in the genesis of migraine [154]. Cytokines are considered to be pain mediators in neurovascular inflammation, which generates migraine pain [155]. They can induce sterile inflammation of meningeal blood vessels in migraines [156]. Besides this, elevated levels of chemokines can stimulate the activation of trigeminal nerves and the release of vasoactive peptides; thereby, they can induce inflammation [157]. Based on these, cytokines and chemokines might contribute to migraine.

\section{Animal models of neurogenic inflammation}

Developing animal models of human illnesses is a challenging task for translational research, but it is indispensable to understanding pathomechanism, searching for biomarkers, and engineering novel treatment [158, 159, 160, 161, 162, 163, 164, 165, 166]. Migraine research is no exception. Chemical activation of meningeal trigeminal nociceptors is possible in animal experiments. The use of Complete Freund's adjuvant (CFA, dried and inactivated Mycobacterium tuberculosis in mineral oil) or inflammatory soup (IS, a standard mixture of histamine, serotonin, bradykinin, and prostaglandin E2) on the surface of the dura mater is a useful method for inducing trigeminal activation and sensitization and developing neurogenic inflammation in rats [167, 168, 169]. It has been shown that trigeminal brainstem neurons have been sensitive to both subarachnoid superfusion and topical IS administration [37, 170]. Lukács et al. demonstrated that the application of CFA or IS onto the dural surface can induce changes in the expression of phosphorylated extracellular signal-regulated kinase $1 / 2$ (pERK1/2), IL-1 $\beta$, and CGRP positive nerve fibers in the TG [169]. Similar to the previous experiment, Laborc et al. used topical administration of IS or CFA on the dura mater to examine the activation pattern that is caused by chemical stimulation and they found that application of IS on the dura mater induces short-term c-Fos activation while CFA did not cause any difference in the number of c-Fos positive cells between the CFA treated and control groups. Whereas short survival times were used, the authors believe this may have been the reason that the CFA did not prove effective [171]. Spekker et al. found, that IS was able to cause sterile neurogenic inflammation in the dura mater and increased the area covered by CGRP and TRPV1 immunoreactive fibers and the number of neuronal nitric oxide synthase (nNOS) positive cells in the TNC and pretreatment with sumatriptan or kynurenic acid could modulate the changes caused by IS. Sumatriptan probably acted through the 5- $\mathrm{HT}_{1 \mathrm{~B} / 1 \mathrm{D}}$ receptors while KYNA possibly acted predominantly by inhibiting the glutamate system 
and thereby blocking sensitization processes, which is important in migraine [172]. Furthermore, Wieseler and colleagues observed an increase in the level of IL-1 $\beta$ and $\mathrm{TNF} \alpha$, and the microglial/macrophage activation marker CD11b in Sp5C after IS was administered bilaterally through supradural catheters in freely moving rats [173].

In addition to morphological changes, IS can also influence animal behavior. Oshinsky and Gomonchareonsiri used IS treatment three times per week for up to 4 weeks and they demonstrated that repeated infusions of IS over weeks induced a long-lasting decrease in periorbital pressure thresholds [174]. Melo-Carrillo and colleagues described that repeated infusion of IS increased the resting and freezing behavior and decreased the locomotor activity [175]. These observations are consistent with decreased routine physical activity and lack of exercise due to migraine-induced pain in migraine patients [176]. Also, they found a specific ipsilateral facial grooming behavior, which may be related to the unilateral nature of migraine. In an animal model of intracranial pain, Malick et al. showed that simultaneous chemical and mechanical stimulation of the dura mater not only increases the number of Fos-positive neurons in the medullary dorsal horn but can reduce the appetite of the rats. [177]. Wieseler et al. experienced facial and hind paw allodynia and after two IS infusion [178]. In a novel large animal model of recurrent migraine, repeated chemical stimulation of the dura mater reduced locomotor behavior, which may mimic a decrease in routine physical activity in people with headaches. In addition, increased scratches and slow movements were observed; these may reflect pain localized to the head area [179] (Figure 3). Based on these experiments, it can be said that dural application of IS triggers activation and sensitization of the trigeminal system. Therefore, this is a relevant animal model of acute migraine.

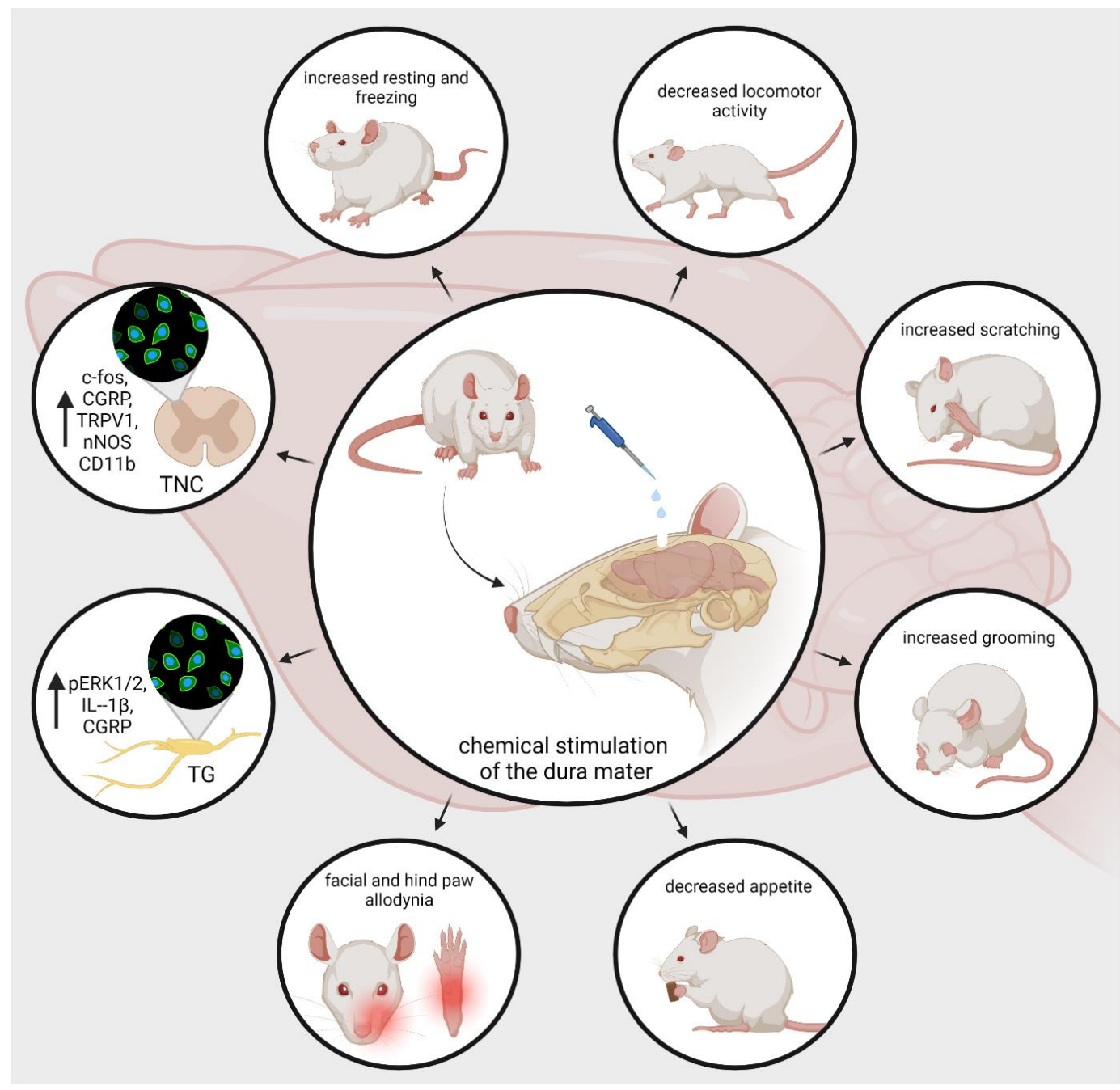


Figure 3. Influence of chemical dural stimulation in animal models. Chemical stimulation of the dura mater leads to several molecular and behavioral changes in animal models. Inflammatory mediators can cause an increase in the levels of several activation and sensitization markers (CGRP, TRPV1, nNOS, pERK, ILs), increase the resting and freezing behavior, and decrease the appetite and locomotor activity of the animals. In addition, it can enhance grooming and scratching behavior and elicit mechanical and thermal hypersensitivity. CGRP: calcitonine gene-related peptide, TRPV1: transient receptor potential vanilloid receptor, nNOS: neuronal nitric-oxide synthase, IL: interleukins, pERK: phosphorylated extracellular signal-regulated kinase

\section{Current treatments and advances in preclinical research}

Triptans are widely used to relieve migraine attacks; acting as agonists on 5-

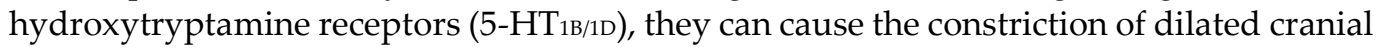
arteries and the inhibition of CGRP release [180]. In an animal model of migraine, after electrical stimulation of the trigeminal ganglion, sumatriptan attenuates PPE by preventing the release of CGRP [181]. In knockout mice and guinea pigs it has been shown that 5-HT1D receptors have a role in the inhibition of neuropeptide release, thereby modifying the dural neurogenic inflammatory response [182]. The use of triptans is limited by their vasoconstrictive properties. As triptans are not effective in everyone, they often lead to medication overuse, triggering migraine to become chronic.

Ditans target the 5- $\mathrm{HT}_{1 \mathrm{~F}}$ receptor which is expressed in the cortex, the hypothalamus, the trigeminal ganglia, the locus coeruleus, the middle cerebral artery, and the upper cervical cord. Lasmiditan is the first drug approved for clinical use. Contrary to triptans, Lasmiditan does not cause vasoconstriction. The activation of 5-HT1F receptor inhibits the release of CGRP and probably SP from the peripheral trigeminal endings of the dura and acts on the trigeminal nucleus caudalis or the thalamus [183].

Besides triptans and ditans, acute treatments of migraine headaches, i.e., ergot alkaloids and nonsteroidal anti-inflammatory agents may decrease the neurogenic inflammatory response [184]. Ergotamine has been recommended to abort migraine attacks by eliminating the constriction of dilated cranial blood vessels and carotid arteriovenous anastomoses, reducing CGRP release from perivascular trigeminal nerve endings, and inhibit the nociceptive transmission on peripheral and central ends of trigeminal sensory nerves [185].

An alternative treatment strategy is the use of CGRP-blocking monoclonal antibodies. Monoclonal antibodies have a number of positive properties: (1) a long halflife, (2) long duration of action, and (3) are highly specific [186]. Four monoclonal antibodies are currently developing for migraine prevention: three against CGRP and one against the CGRP receptor. The safety and tolerability of these antibodies are promising, no clinically significant change in vitals, ECGs, or hepatic enzymes was observed. Blocking of CGRP function by monoclonal antibodies has demonstrated efficacy in the prevention of migraine with minimal side effects in multiple Phase II and III clinical trials [187].

Another alternative approach to treating the migraine attack by limiting neurogenic inflammatory vasodilation is the blockade of CGRP receptors by selective antagonists. Gepants were designed to treat acute migraines [188]. These bind to CGRP receptors and reverse CGRP-induced vasodilation but were not vasoconstrictors per se [189]. Based on these, gepants may be an alternative if triptans are contraindicated, but currently, no gepant is available on the market, but several are in development.

In gene knockout studies have been strengthened the hypothesis that the tachykinins are the primary mediators of the PPE component of NI [190, 191]. Following topical application of capsaicin to the ear, the PPE was decreased in Tac1-deficient mice, compared to wild-type mice [192]. Following activation of the trigeminal system by chemical, mechanical or electrical stimulation, tachykinin Receptor 1 (TACR1) antagonists seem to be adequate to blocking dural PPE [193]. However, lanepitant, a selective TACR1 antagonist, has no significant effect on migraine-associated symptoms [194]; moreover, it was found ineffective in a migraine prevention study [195]. The only currently available 
and clinically approved NK1 receptor antagonist is aprepitant, which is used as an antiemetic to chemotherapy-induced nausea in cancer patients [196].

In animal models, blockage of TRPV1 receptors was effective to reverse inflammatory pain; however, TRPV1 antagonists produce some serious side effects, e.g. hyperthermia [197]. Clinical data suggest that TRPV1 antagonists might be effective as therapeutic options for conditions such as migraine and pain related to several types of diseases. Hopefully, current clinical trials with TRPV1 receptor antagonists and future studies provide an answer as to the role of TRPV1 in inflammatory and neuropathic pain syndromes.

The anti-nociceptive effects of endocannabinoids are thought to be mediated mainly through the activation of cannabinoid receptor type 1 (CB1) [198]. Localization of CB1 receptors along the trigeminal tract and trigeminal afferents $[199,200]$ suggests that the endocannabinoid system can modulate the neurogenic-induced migraine [201]. Clinical data suggested that in migraine patients, the endocannabinoid levels are lower [202, 203]. In animal models of migraine, endocannabinoids can reduce neurogenic inflammation. Akerman et al. reported that capsaicin-induced vasodilation is less after intravenous administration of anandamide (AEA); in addition, AEA significantly prevented CGRPand NO-induced vasodilation in the dura [204]. In a previous study, Nagy-Grócz and colleagues observed that NTG and AEA alone, or combined treatment of them, affects 5HTT expression, which points out a possible interaction between the serotonergic and endocannabinoid system on the NTG-induced trigeminal activation and sensitization phenomenon, which are essential during migraine attacks [205]. These results raise the possibility that the AEA has a CB1 receptor-mediated inhibitory effect on neurogenic vasodilation of trigeminal blood vessels. Based on these, anandamide may be a potential therapeutic target for migraine. Besides these, the presence of CB1 receptors in the brain makes them a target for the treatment of migraine, blocking not only peripheral but also central nociceptive traffic and reducing CSD. CB2 receptors in immune cells may be targeted to reduce the inflammatory component associated with migraine.

PACAP and its G-protein-coupled receptors, pituitary adenylate cyclase 1 receptor (PAC1), vasoactive intestinal peptide receptor 1/2 (VPAC1/2) are involved in various biological processes. Activation of PACAP receptors has an essential role in the pathophysiology of primary headache disorders, and PACAP plays an excitatory role in migraine [206]. There are two pharmacology options to inhibit PACAP: PAC1 receptor antagonists/antibodies directed against the receptor; or antibodies directed against the peptide PACAP [207]. Studies of the PAC1 receptor antagonist PACAP (6-38) have proved that antagonism of this receptor may be beneficial even during migraine progression [208]. PACAP38 and PAC1 receptor blockade are promising antimigraine therapies, but results from clinical trials are needed to confirm their efficacy and side effect profile.

The tryptophan-kynurenine metabolic pathway $(\mathrm{KP})$ is gaining growing attention in search of potential biomarkers and possible therapeutic targets in various illnesses including migraine $[209,210]$. Kynurenic acid (KYNA) is a neuroactive metabolite of the $\mathrm{KP}$, which affects several glutamate receptors, playing a relevant role in pain processing and neuroinflammation [183]. KYNA may block the activation of trigeminal neurons, affect the migraine generators, and modulate the generation of CSD [211]. An abnormal decrease or increase in the KYNA level can cause an imbalance in the neurotransmitter systems, and it is associated with several neurodegenerative and neuropsychiatric disorders [212, 213, 214, 215]. Based on human and animal data, the KP is downregulated under different headaches; thus, possibly less KYNA is produced [216]. It is consistent with the theory of hyperactive NMDA receptors, which play a key role in the development of central sensitization [217] and, thus, in migraine pathophysiology. In an NTG-induced rodent model of migraine, Nagy-Grócz et al. demonstrated a decrease in the expression of KP enzymes after NTG administration in rat TNC [218. Interferons can control the transcription expression of indoleamine 2,3-dioxygenase (IDO), kynurenine 3monooxygenase (KMO), and kynureninase (KYNU); therefore, the pro-inflammatory cytokines may affect kynurenine pathway [219]. KYNA is difficult to cross the blood-brain 
barrier (BBB); therefore, synthetic KYNA analogs may provide an additional alternative for synthesizing compounds that have neuroprotective effects comparable to KYNA can cross the BBB effectively. Preclinical studies have shown the effectiveness of KYNA analogs in animal models of dural stimulation [220, 221]. Further preclinical studies are required to understand the role of KYNA analogs in migraine and clinical studies that assess their effectiveness in acute or prophylactic treatment (Figure 4).

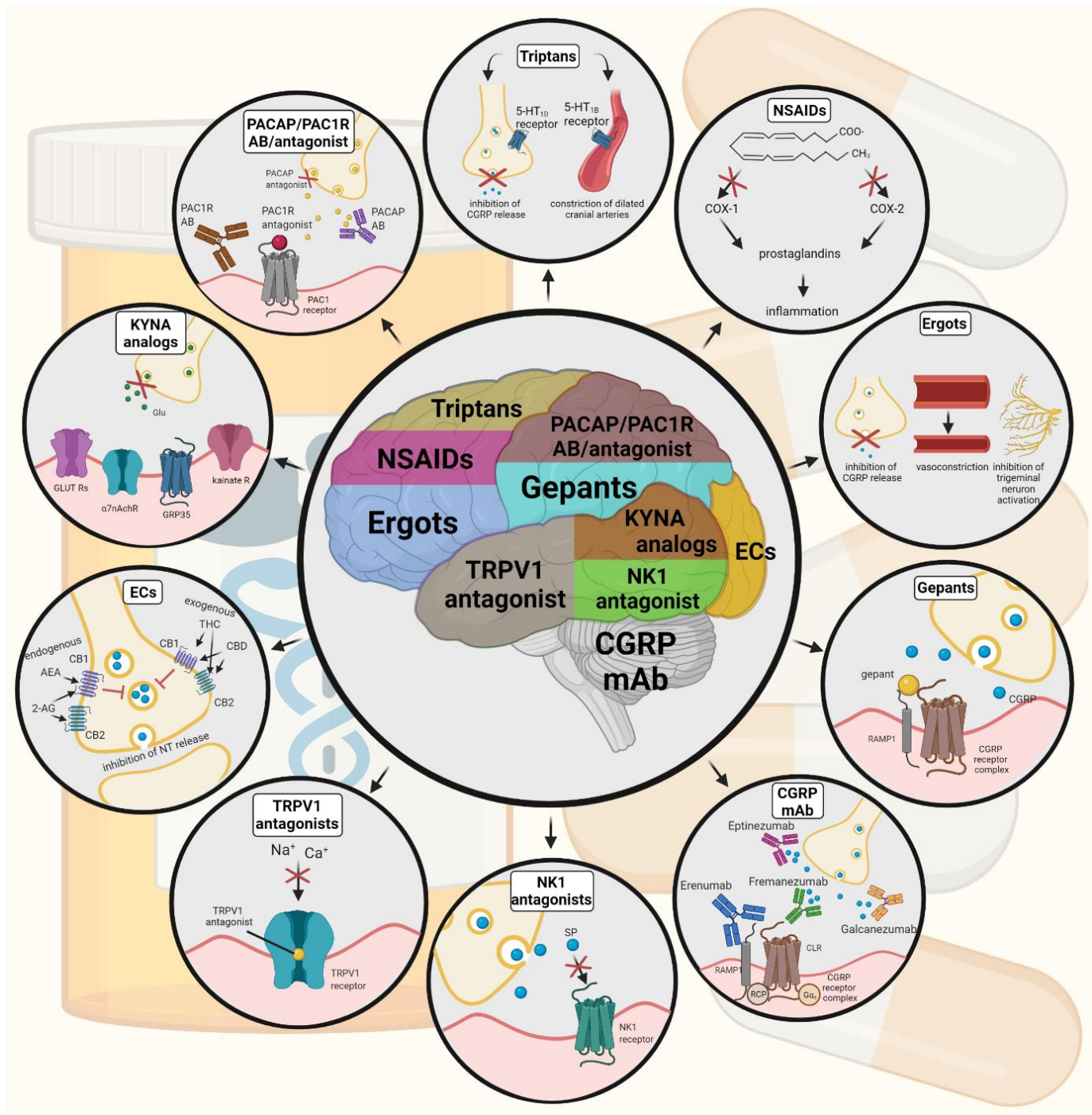

Figure 4. Possible treatments of neurogenic inflammation and migraine. NSAIDs: non-steroidal anti-inflammatory drugs, 5-HT: serotonin, CGRP: calcitonin gene-related peptide, COX: cyclooxygenase, Ab: antibody, NK1: neurokinin 1, TRPV1: transient receptor potential vanilloid receptor, SP: substance P, EC: endocannabinoids, AEA: anandamide, 2-AG: 2-arachidonoylglycerol, CB: cannabinoid receptor, THC: tetrahidrokanabinol, CBD: cannabidiol, NT: neurotransmitter, GLUT R: glutamate receptors, $\alpha 7$ AchR: alpha-7 nicotinic receptor, GPR35: G protein-coupled receptor 35, PACAP: pituitary adenylate cyclase-activating polypeptide, PAC1R: pituitary adenylate cyclase 1 receptor

\section{Conclusion and future perspective}

Migraine imposes a tremendous negative impact on quality of life; nevertheless, antimigraine pharmacotherapy provides limited success in efficacy and tolerability. Migraineurs and patients with chronic pain helplessly seek for alternative or complementary treatments such as biofeedback, botox, yoga, acupuncture, acupressure, and music therapy, among others [222]. The biggest challenge in antimigraine research may lie in complex multifactorial pathogenesis of migraine headache which is precipitated by interwinding genetic, endocrine, metabolic, and/or environmental factors 
and thus, the exact pathology leading to migraine attack remains poorly understood. This review article focuses on that migraine headache is a reflection of neurogenic inflammation in the activation and sensitization of trigeminovascular afferent nerves which project to the second-order neurons in the brainstem. The local release of neuropeptides and neurotransmitters can not only cause the dilation of meningeal vessels, but also induce neuroinflammation. Animal models of migraine support this hypothesis that neurogenic inflammation plays a crucial role in the sensitization process that leads to enhanced responsiveness of target tissues. However, clinical study remains to be conducted. Understanding the signal transduction and regulation of neuropeptides, including CGRP, SP, or neurokinin A may open an approach to discovery of new targets leading to the prevention of neurogenic inflammation.

Moreover, NI can be initiated by chronic stress, diet, hormonal fluctuations, or CSD. The NI triggering factors may become a possible interventional target preventing the initiation of neuroinflammatory cascade. Immune reactions can also participate in NI. But little is known about the interaction of the immune system in NI. Understanding the mechanism of NI trigger is essential in migraine research. Migraine headache is frequently observed in patients with cardiovascular diseases, respiratory diseases, psychiatric diseases, and restless legs syndrome. The disturbance of the serotonergic nervous system, the sympathetic nervous system, the hypothalamic-pituitary-adrenal axis links migraine to mood disorders and obesity. Thus, identifying predisposing factors precipitating to NI trigger may be a potential clue for a novel approach of migraine treatment.

We are untangling the puzzle of the mechanisms behind migraine attacks. However, finding the initial cause and effective treatment remains far away. The translational animal research currently tows forward the field of migraine research and may successfully serve as a savior of migraineurs in the future.

Author Contributions: Conceptualization, E.S.; writing - original draft preparation, E.S.; writingreview and editing, E.S., M.T., Á.S, and L.V.; visualization, E.S.; supervision, L.V.; project administration, L.V.; funding acquisition, M.T. and L.V. All authors have read and agreed to the published version of the manuscript.

Funding: The authors are funded by the Economic Development and Innovation Operational Programme [GINOP 2.3.2-15-2016-00034; GINOP 2.3.2-15-2016-00048], National Research, Development and Innovation Office [NKFIH-1279-2/2020 TKP 2020], TUDFO/47138-1/2019-ITM, and National Scientific Research Fund [OTKA138125].

Acknowledgments: All figures were created with BioRender.com.

Conflicts of Interest: The authors have no other relevant affiliations or financial involvement with any organization or entity with a financial interest in or financial conflict with the subject matter or materials discussed in the manuscript apart from those disclosed.

\begin{tabular}{cc} 
Abbreviations & \\
\hline$\alpha 7$ AchR & alpha-7 nicotinic receptor \\
2-AG & 2-arachidonoylglycerol \\
2-AG & 2-arachidonoylglycerol \\
$5-$ HT$_{1 B / 1 D}$ & 5-hydroxytryptamine receptors \\
$5-$ HT$_{1 B / 1 D}$ & 5-hydroxytryptamine receptors \\
AEA & anandamide, \\
AEA & anandamide, \\
ATP & adenosine triphosphate \\
ATP & adenosine triphosphate \\
BBB & blood-brain barrier \\
cAMP & cyclic adenosine monophosphate \\
cAMP & cyclic adenosine monophosphate \\
CB1 & cannabinoid receptor type 1 \\
\hline
\end{tabular}




\begin{tabular}{|c|c|}
\hline CB1 & cannabinoid receptor type 1 \\
\hline CBD & cannabidiol \\
\hline CBD & cannabidiol \\
\hline CFA & Complete Freund's adjuvant \\
\hline CFA & Complete Freund's adjuvant \\
\hline CGRP & calcitonin gene-related peptide \\
\hline CGRP & calcitonin gene-related peptide \\
\hline CNS & central nervous system \\
\hline CNS & central nervous system \\
\hline CSD & cortical spreading depression \\
\hline CSD & cortical spreading depression \\
\hline CSF & cerebrospinal fluid \\
\hline DR & nucleus raphe dorsalis \\
\hline DRG & dorsal root ganglion \\
\hline GLUT R & glutamate receptors \\
\hline GPR35 & G protein-coupled receptor 35 \\
\hline IDO & indoleamine 2,3-dioxygenase \\
\hline IS & inflammatory soup \\
\hline KMO & kynurenine 3-monooxygenase \\
\hline KP & tryptophan-kynurenine metabolic pathway \\
\hline KYNA & kynurenic acid \\
\hline KYNU & kynureninase \\
\hline LC & locus coeruleus \\
\hline NGF & nerve-growth factor \\
\hline NI & neurogenic inflammation \\
\hline NK1 & neurokinin 1 \\
\hline NKA & neurokinin A \\
\hline nNOS & neuronal nitric oxide synthase \\
\hline NO & nitric oxide \\
\hline NPY & neuropeptide $\mathrm{Y}$ \\
\hline NRM & nucleus raphe magnus \\
\hline NT & neurotransmitter \\
\hline PAC1R & pituitary adenylate cyclase 1 receptor \\
\hline PACAP & pituitary adenylate cyclase-activating polypeptide \\
\hline PAG & the periaqueductal grey matter \\
\hline pERK & phosphorylated extracellular signal-regulated kinase \\
\hline PKA & protein kinase A \\
\hline PKC & protein kinase $C$ \\
\hline PLC & phospholipase C \\
\hline PPE & plasma protein extravasation \\
\hline SP & substance P \\
\hline TACR1 & tachykinin Receptor 1 \\
\hline TG & trigeminal ganglion \\
\hline THC & tetrahidrokannabinol \\
\hline TNC & caudal trigeminal nucleus \\
\hline TNF $\alpha$ & tumor necrosis factor alpha \\
\hline TRPV1 & transient receptor potential vanilloid-1 receptor \\
\hline TS & trigeminal system \\
\hline VIP & vasoactive intestinal peptide \\
\hline VPAC1/2 & vasoactive intestinal peptide receptor $1 / 2$ \\
\hline
\end{tabular}

\section{References}


1. Steiner, T.J.; Stovner, L.J.; Vos, T. GBD 2015: migraine is the third cause of disability in under 50s. J. Headache Pain 2016, 17(1), 104. doi:10.1186/s10194-016-0699-5

2. GBD 2016 Disease and Injury Incidence and Prevalence Collaborators. Global, regional, and national incidence, prevalence, and years lived with disability for 328 diseases and injuries for 195 countries, 1990-2016: a systematic analysis for the Global Burden of Disease Study 2016. Lancet 2017, 390(10100), 1211-1259. doi:10.1016/S01406736(17)32154-2

3. Gazerani, P. ; Cairns, B.E. Sex-Specific Pharmacotherapy for Migraine: A Narrative Review. Front. Neurosci. 2020, 14, 222. doi: $10.3389 /$ fnins.2020.00222

4. Cerbo, R.; Pesare, M.; Aurilia, C.; Rondelli, V.; Barbanti, P. Socio-economic costs of migraine. J. Headache Pain 2001, 2(Suppl 1), s15-s19. doi:10.1007/s101940170003

5. Mayans, L.; Walling, A. Acute Migraine Headache: Treatment Strategies. Am. Fam. Physician 2018, 97(4), $243-251$.

6. Headache Classification Committee of the International Headache Society (IHS). The International Classification of Headache Disorders, 3rd edition (beta version). Cephalalgia. 2013, 33(9), 629-808. doi:10.1177/0333102413485658

7. Headache Classification Subcommittee of the International Headache Society. The International Classification of Headache Disorders: 2nd edition. Cephalalgia 2004, 24 Suppl 1, 9-160. doi:10.1111/j.1468-2982.2003.00824.x

8. Giffin, N.J.; Ruggiero, L.; Lipton, R.B.; Silberstein, S.D.; Tvedskov, J.F.; Olesen, J.; Altman, J.; Goadsby, P.J.; Macrae, A. Premonitory symptoms in migraine: an electronic diary study. Neurology 2003, 60(6), 935-940. doi:10.1212/01.wnl.0000052998.58526.a9

9. Lai, J.; Dilli, E. Migraine Aura: Updates in Pathophysiology and Management. Curr. Neurol. Neurosci. Rep. 2020, 20(6), 17. doi:10.1007/s11910-020-01037-3

10. van Dongen, R.M.; Haan, J. Symptoms related to the visual system in migraine. F1000Res. 2019, 8, F1000 Faculty Rev1219. doi:10.12688/f1000research.18768.1

11. Pescador Ruschel, M.A.; De Jesus, O. Migraine Headache. In StatPearls; StatPearls Publishing: Treasure Island, FL, USA. Available online: https://www.ncbi.nlm.nih.gov/books/NBK560787/ (accessed on 27 October 2021).

12. Chen, P.K.; Wang, S.J. Non-headache symptoms in migraine patients. F1000Res. 2018, 7, 188. doi:10.12688/f1000research.12447.1

13. Goadsby, P.J.; Holland, P.R.; Martins-Oliveira, M.; Hoffmann, J.; Schankin, C.; Akerman, S. Pathophysiology of Migraine: A Disorder of Sensory Processing. Physiol. Rev. 2017, 97(2), 553-622. doi:10.1152/physrev.00034.2015

14. Edvinsson, L. Tracing neural connections to pain pathways with relevance to primary headaches. Cephalalgia 2011, 31(6), 737-747. doi:10.1177/0333102411398152

15. Fusco, B.M.; Barzoi, G.; Agrò, F. Repeated intranasal capsaicin applications to treat chronic migraine. Br. J. Anaesth 2003, 90(6), 812. doi:10.1093/bja/aeg572

16. Cross, S.A. Pathophysiology of pain. Mayo. Clin. Proc. 1994, 69(4), 375-383. doi:10.1016/s0025-6196(12)62225-3

17. Matharu, M.S.; Bartsch, T.; Ward, N.; Frackowiak, R.S.; Weiner, R.; Goadsby, P.J. Central neuromodulation in chronic migraine patients with suboccipital stimulators: a PET study. Brain 2004, 127(Pt 1), 220-230. doi:10.1093/brain/awh022

18. Vincent, M.; Hadjikhani, N. The cerebellum and migraine. Headache 2007, 47(6), 820-833. doi:10.1111/j.15264610.2006.00715.x

19. Ray, B.S.; Wolff, H.G. Experimental studies on headache: Pain sensitive structures of the head and their significance in headache. Headache Arch. Surg. 1940, 41(4), 813-856. doi:10.1001/archsurg.1940.01210040002001

20. Tunis, M.M.; Wolff, H.G. Studies on headache; long-term observations of the reactivity of the cranial arteries in subjects with vascular headache of the migraine type. AMA Arch. Neurol. Psychiatry 1953, 70(5), 551-557.

21. Leao, A.A.P.; Morison, R.S. Propagation of spreading cortical depression. Journal of Neurophysiology 1945, 8:1, 33-45. doi:10.1152/jn.1945.8.1.33

22. Ayata, C. Cortical spreading depression triggers migraine attack: pro. Headache 2010, 50(4), 725-730. doi:10.1111/j.15264610.2010.01647.x

23. Lauritzen, M. Pathophysiology of the migraine aura. The spreading depression theory. Brain 1994, 117 ( Pt 1), $199-210$. doi:10.1093/brain/117.1.199

24. Olesen, J.; Goadsby, P.J. Synthesis of migraine mechanisms. In: The Headaches 2nd ed; Olesen, J.; Tfelt-Hansen, P.; Welch, K.M.A., Eds.; Lippincott Williams \& Wilkins: Philadelphia, PA, USA, 2000; pp. 331-336.

25. Moskowitz, M.A. Defining a pathway to discovery from bench to bedside: the trigeminovascular system and sensitization. Headache 2008, 48(5), 688-690. doi:10.1111/j.1526-4610.2008.01110.x

26. Weiller, C.; May, A.; Limmroth, V.; Jüptner, M.; Kaube, H.; Schayck, R.V.; Coenen, H.H.; Diener, H.C. Brain stem activation in spontaneous human migraine attacks. Nat. Med. 1995, 1(7), 658-660. doi:10.1038/nm0795-658

27. Edvinsson, L.; Goadsby, P.J. Neuropeptides in the Cerebral Circulation: Relevance to Headache. Cephalalgia 1995, 15(4), 272-276. doi:10.1046/j.1468-2982.1995.1504272.x

28. Akerman, S.; Holland, P.R.; Goadsby, P.J. Diencephalic and brainstem mechanisms in migraine. Nat. Rev. Neurosci. 2011, 12(10), 570-584. doi:10.1038/nrn3057

29. Fleetwood-Walker, S.M.; Hope, P.J.; Mitchell, R. Antinociceptive actions of descending dopaminergic tracts on cat and rat dorsal horn somatosensory neurones. J. Physiol. 1988, 399, 335-348. doi:10.1113/jphysiol.1988.sp017084

30. Settle, M. The hypothalamus. Neonatal Netw. 2000, 19(6), 9-14. doi:10.1891/0730-0832.19.6.9

31. Witten, A.; Marotta, D.; Cohen-Gadol, A. Developmental innervation of cranial dura mater and migraine headache: A narrative literature review. Headache 2021, 61(4), 569-575. doi:10.1111/head.14102 
32. Rozen, T.; Swidan, S.Z. Elevation of CSF tumor necrosis factor alpha levels in new daily persistent headache and treatment refractory chronic migraine. Headache 2007, 47(7), 1050-1055. doi:10.1111/j.1526-4610.2006.00722.x

33. Dowgjallo, N. Über die Nerven der harten Hirnhaut des Menschen und einiger Säuger. Z. Anat. Entwickl. Gesch. 1929, 89, 453-466. doi:10.1007/BF02117630

34. Grzybowski J. L'innervation de la dure - mére cranienne chez l'homme. Arch. Anat. Histol. Embryol. 1931, 14, 387-428.

35. Penfield, W.; McNaughton, F. Dural headache and innervation of the dura mater. Arch. NeurPsych. 1940, 44(1), 43-75. doi:10.1001/archneurpsyc.1940.02280070051003

36. Steiger, H.J.; Meakin, C.J. The meningeal representation in the trigeminal ganglion--an experimental study in the cat. Headache 1984, 24(6), 305-309. doi:10.1111/j.1526-4610.1984.hed2406305.x

37. Uddman, R.; Hara, H.; Edvinsson, L. Neuronal pathways to the rat middle meningeal artery revealed by retrograde tracing and immunocytochemistry. J. Auton. Nerv. Syst. 1989, 26(1), 69-75. doi:10.1016/0165-1838(89)90109-4

38. Strassman, A.M.; Raymond, S.A.; Burstein, R. Sensitization of meningeal sensory neurons and the origin of headaches. Nature 1996, 384(6609), 560-4. doi: 10.1038/384560a0

39. Burstein, R.; Yamamura, H.; Malick, A.; Strassman, A.M. Chemical stimulation of the intracranial dura induces enhanced responses to facial stimulation in brain stem trigeminal neurons. J. Neurophysiol. 1998, 79(2), 964-982. doi:10.1152/jn.1998.79.2.964

40. Amenta, F.; Sancesario, G.; Ferrante, F.; Cavallotti, C. Acetylcholinesterase-containing nerve fibers in the dura mater of guinea pig, mouse, and rat. J. Neural. Transm. 1980, 47(3), 237-242. doi:10.1007/BF01250604

41. Schueler, M.; Neuhuber, W.L.; De Col, R.; Messlinger, K. Innervation of rat and human dura mater and pericranial tissues in the parieto-temporal region by meningeal afferents. Headache 2014, 54(6), 996-1009. doi:10.1111/head.12371

Ebersberger, A.; Averbeck, B.; Messlinger, K.; Reeh, P.W. Release of substance P, calcitonin gene-related peptide and prostaglandin E2 from rat dura mater encephali following electrical and chemical stimulation in vitro. Neuroscience 1999, 89(3), 901-907. doi:10.1016/s0306-4522(98)00366-2

43. Lv, X.; Wu, Z.; Li, Y. Innervation of the cerebral dura mater. Neuroradiol. J. 2014, 27(3), 293-298. doi:10.15274/NRJ-201410052

44. Asghar, M.S.; Hansen, A.E.; Amin, F.M.; van der Geest, R.J.; Koning, P.V.; Larsson, H.B.; Olesen, J.; Ashina, M. Evidence for a vascular factor in migraine. Ann. Neurol. 2011, 69(4), 635-645. doi:10.1002/ana.22292

45. Holzer, P. Neurogenic vasodilatation and plasma leakage in the skin. Gen. Pharmacol. 1998, 30(1), 5-11. doi:10.1016/s0306-3623(97)00078-5

46. Ottosson, A.; Edvinsson L. Release of histamine from dural mast cells by substance P and calcitonin gene-related peptide. Cephalalgia 1997, 17(3), 166-174. doi:10.1046/j.1468-2982.1997.1703166.x

47. Lennerz, J.K.; Rühle, V.; Ceppa, E.P.; Neuhuber, W.L.; Bunnett, N.W.; Grady, E.F.; Messlinger, K. Calcitonin receptorlike receptor (CLR), receptor activity-modifying protein 1 (RAMP1), and calcitonin gene-related peptide (CGRP) immunoreactivity in the rat trigeminovascular system: differences between peripheral and central CGRP receptor distribution. J. Comp. Neurol. 2008, 507(3), 1277-1299. doi:10.1002/cne.21607

48. Raddant, A.C.; Russo, A.F. Calcitonin gene-related peptide in migraine: intersection of peripheral inflammation and central modulation. Expert Rev. Mol. Med. 2011, 13, e36. doi:10.1017/S1462399411002067

49. Hökfelt, T.; Kellerth, J.O.; Nilsson, G.; Pernow, B. Substance p: localization in the central nervous system and in some primary sensory neurons. Science 1975, 190(4217), 889-890. doi:10.1126/science.242075

50. Ribeiro-da-Silva, A.; Hökfelt, T. Neuroanatomical localisation of Substance P in the CNS and sensory neurons. Neuropeptides 2000, 34(5), 256-271. doi:10.1054/npep.2000.0834

51. Snijdelaar, D.G.; Dirksen, R.; Slappendel, R.; Crul, B.J. Substance P. Eur. J. Pain 2000, 4(2), 121-135. doi:10.1053/eujp.2000.0171

52. Graefe, S.; Mohiuddin, S.S. Biochemistry, Substance P. In StatPearls; StatPearls Publishing: Treasure Island, FL, USA. Available online: https://www.ncbi.nlm.nih.gov/books/NBK554583/ (accessed on 27 October 2021).

53. Killingsworth, C.R.; Shore, S.A.; Alessandrini, F.; Dey, R.D.; Paulauskis, J.D. Rat alveolar macrophages express preprotachykinin gene-I mRNA-encoding tachykinins. Am. J. Physiol. 1997, 273(5), L1073-L1081. doi:10.1152/ajplung.1997.273.5.L1073

54. Weinstock, J.V.; Blum, A.; Walder, J.; Walder, R. Eosinophils from granulomas in murine schistosomiasis mansoni produce substance P. J. Immunol. 1988, 141(3), 961-966.

55. Holzer, P.; Holzer-Petsche, U. Tachykinins in the gut. Part II. Roles in neural excitation, secretion and inflammation. Pharmacol. Ther. 1997, 73(3), 219-263. doi:10.1016/s0163-7258(96)00196-9

56. Pernow, B. Substance P. Pharmacol. Rev. 1983, 35(2), 85-141.

57. Gibbins, I.L.; Furness, J.B.; Costa, M.; MacIntyre, I.; Hillyard, C.J.; Girgis, S. Co-localization of calcitonin gene-related peptide-like immunoreactivity with substance $\mathrm{P}$ in cutaneous, vascular and visceral sensory neurons of guinea pigs. Neurosci. Lett. 1985, 57(2), 125-130. doi:10.1016/0304-3940(85)90050-3

58. Battaglia, G.; Rustioni, A. Coexistence of glutamate and substance $\mathrm{P}$ in dorsal root ganglion neurons of the rat and monkey. J. Comp. Neurol. 1988, 277(2), 302-312. doi:10.1002/cne.902770210

59. Malhotra, R. Understanding migraine: Potential role of neurogenic inflammation. Ann. Indian Acad. Neurol. 2016, 19(2), 175-182. doi:10.4103/0972-2327.182302

60. Jansen-Olesen, I.; Hougaard Pedersen, S. PACAP and its receptors in cranial arteries and mast cells. J. Headache Pain 2018, 19(1), 16. doi:10.1186/s10194-017-0822-2 
61. Eftekhari, S.; Warfvinge, K.; Blixt, F.W.; Edvinsson, L. Differentiation of nerve fibers storing CGRP and CGRP receptors in the peripheral trigeminovascular system. J. Pain 2013, 14(11), 1289-1303. doi:10.1016/j.jpain.2013.03.010

62. Nielsen, H.S.; Hannibal, J.; Fahrenkrug, J. Embryonic expression of pituitary adenylate cyclase-activating polypeptide in sensory and autonomic ganglia and in spinal cord of the rat. J. Comp. Neurol. 1998, 394(4), 403-415. doi:10.1002/(sici)1096-9861(19980518)394:4<403::aid-cne1>3.0.co;2-5

63. Jansen-Olesen, I.; Baun, M.; Amrutkar, D.V.; Ramachandran, R.; Christophersen, D.V.; Olesen, J. PACAP-38 but not VIP induces release of CGRP from trigeminal nucleus caudalis via a receptor distinct from the PAC1 receptor. Neuropeptides 2014, 48(2), 53-64. doi:10.1016/j.npep.2014.01.004

64. Uddman, R.; Tajti, J.; Hou, M.; Sundler, F.; Edvinsson, L. Neuropeptide expression in the human trigeminal nucleus caudalis and in the cervical spinal cord C1 and C2. Cephalalgia 2002, 22(2), 112-116. doi:10.1046/j.1468-2982.2002.00324.x

65. Hashimoto, H.; Shintani, N.; Baba, A. New insights into the central PACAPergic system from the phenotypes in PACAP- and PACAP receptor-knockout mice. Ann. N. Y. Acad. Sci. 2006, 1070, 75-89. doi:10.1196/annals.1317.038

66. Martin, M.; Otto, C.; Santamarta, M.T.; Torrecilla, M.; Pineda, J.; Schütz, G.; Maldonado, R. Morphine withdrawal is modified in pituitary adenylate cyclase-activating polypeptide type I-receptor-deficient mice. Brain Res. Mol. Brain Res. 2003, 110(1), 109-118. doi:10.1016/s0169-328x(02)00646-0

67. Missig, G.; Roman, C.W.; Vizzard, M.A.; Braas, K.M.; Hammack, S.E.; May, V. Parabrachial nucleus (PBn) pituitary adenylate cyclase activating polypeptide (PACAP) signaling in the amygdala: implication for the sensory and behavioral effects of pain. Neuropharmacology 2014, 86, 38-48. doi:10.1016/j.neuropharm.2014.06.022

68. Kaiser, E.A.; Russo, A.F. CGRP and migraine: could PACAP play a role too? Neuropeptides 2013, 47(6), 451-461. doi:10.1016/j.npep.2013.10.010

69. Zhang, Y.; Danielsen, N.; Sundler, F.; Mulder, H. Pituitary adenylate cyclase-activating peptide is upregulated in sensory neurons by inflammation. Neuroreport 1998, 9(12), 2833-2836. doi:10.1097/00001756-199808240-00027

70. Kilinc, E.; Firat, T.; Tore, F.; Kiyan, A.; Kukner, A.; Tunçel, N. Vasoactive Intestinal peptide modulates c-Fos activity in the trigeminal nucleus and dura mater mast cells in sympathectomized rats. J. Neurosci. Res. 2015, 93(4), 644-650. doi:10.1002/jnr.23523

71. Ohhashi, T.; Olschowka, J.A.; Jacobowitz, D.M. Vasoactive intestinal peptide inhibitory innervation in bovine mesenteric lymphatics. A histochemical and pharmacological study. Circ. Res. 1983, 53(4), 535-538. doi:10.1161/01.res.53.4.535

72. Kakurai, M.; Fujita, N.; Murata, S.; Furukawa, Y.; Demitsu, T.; Nakagawa, H. Vasoactive intestinal peptide regulates its receptor expression and functions of human keratinocytes via type I vasoactive intestinal peptide receptors. J. Invest. Dermatol. 2001, 116(5), 743-749. doi:10.1046/j.1523-1747.2001.01306.x

73. Cernuda-Morollón, E.; Martínez-Camblor, P.; Ramón, C.; Larrosa, D.; Serrano-Pertierra, E.; Pascual, J. CGRP and VIP levels as predictors of efficacy of Onabotulinumtoxin type A in chronic migraine. Headache 2014, 54(6), 987-995. doi:10.1111/head.12372

74. Pellesi, L.; Al-Karagholi, M.A.; Chaudhry, B.A.; Lopez, C.L.; Snellman, J.; Hannibal, J.; Amin, F.M.; Ashina, M. Twohour infusion of vasoactive intestinal polypeptide induces delayed headache and extracranial vasodilation in healthy volunteers. Cephalalgia 2020, 40(11), 1212-1223. doi:10.1177/0333102420937655

75. Caterina, M.J.; Leffler, A.; Malmberg, A.B.; Martin, W.J.; Trafton, J.; Petersen-Zeitz, K.R.; Koltzenburg, M.; Basbaum, A.I.; Julius, D. Impaired nociception and pain sensation in mice lacking the capsaicin receptor. Science 2000, 288(5464), 306-313. doi:10.1126/science.288.5464.306

76. Quartu, M.; Serra, M.P.; Boi, M.; Poddighe, L.; Picci, C.; Demontis, R.; Del Fiacco, M. TRPV1 receptor in the human trigeminal ganglion and spinal nucleus: immunohistochemical localization and comparison with the neuropeptides CGRP and SP. J. Anat. 2016, 229(6), 755-767. doi:10.1111/joa.12529

77. Dux, M.; Rosta, J.; Messlinger, K. TRP Channels in the Focus of Trigeminal Nociceptor Sensitization Contributing to Primary Headaches. Int. J. Mol. Sci. 2020, 21(1), 342. doi:10.3390/ijms21010342

78. Bevan, S.; Quallo, T.; Andersson, D.A. TRPV1. Handb. Exp. Pharmacol. 2014, 222, 207-245. doi:10.1007/978-3-642-542152_9

79. Meents, J.E.; Neeb, L.; Reuter, U. TRPV1 in migraine pathophysiology. Trends Mol. Med. 2010, 16(4), $153-159$. doi:10.1016/j.molmed.2010.02.004

80. Yuan, H.; Silberstein, S.D. Histamine and Migraine. Headache 2018, 58(1), 184-193. doi:10.1111/head.13164

81. Castillo, J.; Martínez, F.; Corredera, E.; Lema, M.; Noya, M. Migraña e histamina: determinación de histidina en plasma y líquido cefalorraquídeo durante crisis de migraña [Migraine and histamine: determining histidine in plasma and cerebrospinal fluid during migraine attacks]. Rev. Neurol. 1995, 23(122), 749-751.

82. Heatley, R.V.; Denburg, J.A.; Bayer, N.; Bienenstock, J. Increased plasma histamine levels in migraine patients. Clin. Allergy 1982, 12(2), 145-149. doi:10.1111/j.1365-2222.1982.tb01633.x

83. Foreman, J.C.; Jordan, C.C.; Oehme, P.; Renner, H. Structure-activity relationships for some substance P-related peptides that cause wheal and flare reactions in human skin. J. Physiol. 1983, 335, 449-465. doi:10.1113/jphysiol.1983.sp014543

84. Rosa, A.C.; Fantozzi, R. The role of histamine in neurogenic inflammation. Br. J. Pharmacol. 2013, 170(1), 38-45. doi:10.1111/bph.12266

85. Goadsby, P.J.; Knight, Y.E.; Hoskin, K.L.; Butler, P. Stimulation of an intracranial trigeminally-innervated structure selectively increases cerebral blood flow. Brain Res. 1997, 751(2), 247-252. doi:10.1016/s0006-8993(96)01344-3 
86. Ji, R.R.; Xu, Z.Z.; Gao, Y.J. Emerging targets in neuroinflammation-driven chronic pain. Nat. Rev. Drug Discov. 2014, 13(7), 533-548. doi:10.1038/nrd4334

87. Goltz, F. Uber gefasserweiternde nerven. Pflueger Arch. Ges. Physiol. 1874, 9, 185.

88. Bayliss, W.M. On the origin from the spinal cord of the vaso-dilator fibres of the hind-limb, and on the nature of these fibres. J. Physiol. 1901, 26(3-4), 173-209. doi: 10.1113/jphysiol.1901.sp000831.

89. Dalessio, D.J. Vascular permeability and vasoactive substances: Their relationship to migraine. Adv. Neurol. 1974, 4, 395-401.

90. Moskowitz, M.A. The neurobiology of vascular head pain. Ann. Neurol. 1984, 16(2), 157-168. doi:10.1002/ana.410160202

91. Ramachandran, R. Neurogenic inflammation and its role in migraine. Semin. Immunopathol. 2018, 40(3), 301-314. doi:10.1007/s00281-018-0676-y

92. Bolay, H.; Reuter, U.; Dunn, A.K.; Huang, Z.; Boas, D.A.; Moskowitz, M.A. Intrinsic brain activity triggers trigeminal meningeal afferents in a migraine model. Nat. Med. 2002, 8(2), 136-142. doi:10.1038/nm0202-136

93. Xanthos, D.N.; Sandkühler, J. Neurogenic neuroinflammation: inflammatory CNS reactions in response to neuronal activity. Nat. Rev. Neurosci. 2014, 15(1), 43-53.

94. Tajti, J.; Szok, D.; Majláth, Z.; Tuka, B.; Csáti, A.; Vécsei, L. Migraine and neuropeptides. Neuropeptides 2015, 52, 19-30.

95. Berger, R.J.; Zuccarello, M.; Keller, J.T. Nitric oxide synthase immunoreactivity in the rat dura mater. Neuroreport 1994, 5(4), 519-521. doi: 10.1097/00001756-199401120-00039

96. Wallace, J.L. Nitric oxide as a regulator of inflammatory processes. Mem. Inst. Oswaldo Cruz 2005,100 Suppl 1, 5-9. doi:10.1590/s0074-02762005000900002

97. Bellamy, J.; Bowen, E.J.; Russo, A.F.; Durham, P.L. Nitric oxide regulation of calcitonin gene-related peptide gene expression in rat trigeminal ganglia neurons. Eur. J. Neurosci. 2006, 23(8), 2057-2066. doi:10.1111/j.1460-9568.2006.04742.x

98. Strecker, T.; Dux, M.; Messlinger, K. Increase in meningeal blood flow by nitric oxide--interaction with calcitonin generelated peptide receptor and prostaglandin synthesis inhibition. Cephalalgia 2002, 22(3), 233-241. doi:10.1046/j.14682982.2002.00356.x

99. Leston, J.M. Anatomie fonctionnelle du nerf trijumeau [Functional anatomy of the trigeminal nerve]. Neurochirurgie 2009, 55(2), 99-112. French. doi: 10.1016/j.neuchi.2009.01.001

100. Pedersen, S.F.; Owsianik, G.; Nilius, B. TRP channels: an overview. Cell Calcium 2005, 38(3-4), $233-252$. doi:10.1016/j.ceca.2005.06.028

101. Planells-Cases, R.; Garcia-Sanz, N.; Morenilla-Palao, C.; Ferrer-Montiel, A. Functional aspects and mechanisms of TRPV1 involvement in neurogenic inflammation that leads to thermal hyperalgesia. Pflugers Arch. 2005, 451(1), 151-159. doi:10.1007/s00424-005-1423-5

102. Bhave, G.; Zhu, W.; Wang, H.; Brasier, D.J.; Oxford, G.S.; Gereau, R.W. 4th. cAMP-dependent protein kinase regulates desensitization of the capsaicin receptor (VR1) by direct phosphorylation. Neuron 2002, 35(4), $721-731$. doi:10.1016/s0896-6273(02)00802-4

103. Crandall, M.; Kwash, J.; Yu, W.; White, G. Activation of protein kinase C sensitizes human VR1 to capsaicin and to moderate decreases in $\mathrm{pH}$ at physiological temperatures in Xenopus oocytes. Pain 2002, 98(1-2), 109-117. doi:10.1016/s0304-3959(02)00034-9

104. Premkumar, L.S.; Ahern, G.P. Induction of vanilloid receptor channel activity by protein kinase C. Nature 2000, 408(6815), 985-990. doi:10.1038/35050121

105. Vellani, V.; Mapplebeck, S.; Moriondo, A.; Davis, J.B.; McNaughton, P.A. Protein kinase C activation potentiates gating of the vanilloid receptor VR1 by capsaicin, protons, heat and anandamide. J. Physiol. 2001, 534(Pt 3), 813-825. doi:10.1111/j.1469-7793.2001.00813.x

106. Vergnolle, N.; Cenac, N.; Altier, C.; Cellars, L.; Chapman, K.; Zamponi, G.W.; Materazzi, S.; Nassini, R.; Liedtke, W.; Cattaruzza, F.; Grady, E.F.; Geppetti, P.; Bunnett, N.W. A role for transient receptor potential vanilloid 4 in tonicityinduced neurogenic inflammation. Br. J. Pharmacol. 2010, 159(5), 1161-1173. doi:10.1111/j.1476-5381.2009.00590.x

107. Perini, F.; D'Andrea, G.; Galloni, E.; Pignatelli, F.; Billo, G.; Alba, S.; Bussone, G.; Toso, V. Plasma cytokine levels in migraineurs and controls. Headache 2005, 45(7), 926-931. doi:10.1111/j.1526-4610.2005.05135.x

108. Sarchielli, P.; Alberti, A.; Baldi, A.; Coppola, F.; Rossi, C.; Pierguidi, L.; Floridi, A.; Calabresi, P. Proinflammatory cytokines, adhesion molecules, and lymphocyte integrin expression in the internal jugular blood of migraine patients without aura assessed ictally. Headache 2006, 46(2), 200-207. doi:10.1111/j.1526-4610.2006.00337.x

109. Jacobs, B.; Dussor, G. Neurovascular contributions to migraine: Moving beyond vasodilation. Neuroscience 2016, 338, 130-144. doi:10.1016/j.neuroscience.2016.06.012

110. Breier, G.; Risau, W. The role of vascular endothelial growth factor in blood vessel formation. Trends Cell Biol. 1996, 6(12), 454-456. doi:10.1016/0962-8924(96)84935-x

111. Palmer, R.M.; Ashton, D.S.; Moncada, S. Vascular endothelial cells synthesize nitric oxide from L-arginine. Nature 1988, 333(6174), 664-666. doi:10.1038/333664a0

112. Mantovani, A.; Sozzani, S.; Introna, M. Endothelial activation by cytokines. Ann. N. Y. Acad. Sci. 1997, 832, 93-116. doi:10.1111/j.1749-6632.1997.tb46240.x

113. Malhotra, R. Understanding migraine: Potential role of neurogenic inflammation. Ann. Indian Acad. Neurol. 2016, 19(2), 175-182. doi:10.4103/0972-2327.182302

114. Yonehara, N.; Yoshimura, M. Effect of nitric oxide on substance P release from the peripheral endings of primary afferent neurons. Neurosci. Lett. 1999, 271(3), 199-201. doi:10.1016/s0304-3940(99)00533-9 
115. Price, T.J.; Louria, M.D.; Candelario-Soto, D.; Dussor, G.O.; Jeske, N.A.; Patwardhan, A.M.; Diogenes, A.; Trott, A.A.; Hargreaves. K.M.; Flores, C.M. Treatment of trigeminal ganglion neurons in vitro with NGF, GDNF or BDNF: effects on neuronal survival, neurochemical properties and TRPV1-mediated neuropeptide secretion. BMC Neurosci. 2005, 6, 4. doi:10.1186/1471-2202-6-4

116. Miyoshi, H.; Nakaya, Y. Calcitonin gene-related peptide activates the K+ channels of vascular smooth muscle cells via adenylate cyclase. Basic Res. Cardiol. 1995, 90(4), 332-336. doi:10.1007/BF00797911

117. Hanko, J.; Hardebo, J.E.; Kåhrström, J.; Owman, C.; Sundler, F. Calcitonin gene-related peptide is present in mammalian cerebrovascular nerve fibres and dilates pial and peripheral arteries. Neurosci. Lett. 1985, 57(1), 91-95. doi:10.1016/03043940(85)90045-x

118. Wilkins, B.W.; Chung, L.H.; Tublitz, N.J.; Wong, B.J.; Minson, C.T. Mechanisms of vasoactive intestinal peptidemediated vasodilation in human skin. J. Appl. Physiol. (1985) 2004, 97(4), 1291-1298. doi:10.1152/japplphysiol.00366.2004

119. Williamson, D.J.; Hargreaves, R.J. Neurogenic inflammation in the context of migraine. Microsc. Res. Tech. 2001, 53(3), 167-178. doi:10.1002/jemt.1081

120. Markowitz, S.; Saito, K.; Moskowitz, M.A. Neurogenically mediated plasma extravasation in dura mater: effect of ergot alkaloids. A possible mechanism of action in vascular headache. Cephalalgia 1988, 8(2), 83-91. doi:10.1046/j.14682982.1988.0802083.x

121. Lundy, F.T.; Linden, G.J. Neuropeptides and neurogenic mechanisms in oral and periodontal inflammation. Crit. Rev. Oral Biol. Med. 2004, 15(2), 82-98. doi:10.1177/154411130401500203

122. Foreman, J.C.; Jordan, C.C.; Oehme, P.; Renner, H. Structure-activity relationships for some substance P-related peptides that cause wheal and flare reactions in human skin. J. Physiol. 1983, 335, 449-465. doi:10.1113/jphysiol.1983.sp014543

123. De Swert, K.O.; Joos, G.F. Extending the understanding of sensory neuropeptides. Eur. J. Pharmacol. 2006, 533(1-3), 171181. doi:10.1016/j.ejphar.2005.12.066

124. Koyuncu Irmak, D.; Kilinc, E.; Tore, F. Shared Fate of Meningeal Mast Cells and Sensory Neurons in Migraine. Front Cell Neurosci. 2019, 13, 136. doi:10.3389/fncel.2019.00136

125. Theoharides, T.C.; Spanos, C.; Pang, X.; Alferes, L.; Ligris, K.; Letourneau, R.; Rozniecki, J.J.; Webster, E.; Chrousos, G.P. Stress-induced intracranial mast cell degranulation: a corticotropin-releasing hormone-mediated effect. Endocrinology 1995, 136(12), 5745-5750. doi:10.1210/endo.136.12.7588332

126. Rozniecki, J.J.; Dimitriadou, V.; Lambracht-Hall, M.; Pang, X.; Theoharides, T.C. Morphological and functional demonstration of rat dura mater mast cell-neuron interactions in vitro and in vivo. Brain Res. 1999, 849(1-2), 1-15. doi:10.1016/s0006-8993(99)01855-7

127. Theoharides, T.C.; Donelan, J.; Kandere-Grzybowska, K.; Konstantinidou, A. The role of mast cells in migraine pathophysiology. Brain Res. Brain Res. Rev. 2005, 49(1), 65-76. doi:10.1016/j.brainresrev.2004.11.006

128. Schwartz, L.B. Mediators of human mast cells and human mast cell subsets [published correction appears in Ann. Allergy 1987, 59(4), 316]. Ann. Allergy 1987, 58(4), 226-235.

129. Aich, A.; Afrin, L.B.; Gupta, K. Mast Cell-Mediated Mechanisms of Nociception. Int. J. Mol. Sci. 2015, 16(12), 2906929092. doi:10.3390/ijms161226151

130. Theoharides, T.C.; Alysandratos, K.D.; Angelidou, A.; Delivanis, D.A.; Sismanopoulos, N.; Zhang, B.; Asadi, S.; Vasiadi, M.; Weng, Z.; Miniati, A.; Kalogeromitros, D. Mast cells and inflammation. Biochim. Biophys. Acta. 2012, 1822(1), 21-33. doi:10.1016/j.bbadis.2010.12.014

131. Karatas, H.; Erdener, S.E.; Gursoy-Ozdemir, Y.; Lule, S.; Eren-Koçak, E.; Sen, Z.D.; Dalkara, T. Spreading depression triggers headache by activating neuronal Panx1 channels [published correction appears in Science 2015, 350(6256), aad5166] [published correction appears in Science 2015, 350(6263), 921]. Science 2013, 339(6123), $1092-1095$. doi:10.1126/science.1231897

132. Zhao, J.; Levy, D. Modulation of intracranial meningeal nociceptor activity by cortical spreading depression: a reassessment. J. Neurophysiol. 2015, 113(7), 2778-2785. doi:10.1152/jn.00991.2014

133. Kempuraj, D.; Selvakumar, G.P.; Thangavel, R.; Ahmed, M.E.; Zaheer, S.; Raikwar, S.P.; Iyer, S.S.; Bhagavan, S.M.; Beladakere-Ramaswamy, S.; Zaheer, A. Mast Cell Activation in Brain Injury, Stress, and Post-traumatic Stress Disorder and Alzheimer's Disease Pathogenesis. Front. Neurosci. 2017, 11, 703. doi:10.3389/fnins.2017.00703

134. Baldwin, A.L. Mast cell activation by stress. Methods Mol. Biol. 2006, 315, 349-360. doi:10.1385/1-59259-967-2:349

135. Sauro, K.M.; Becker, W.J. The stress and migraine interaction. Headache 2009, 49(9), 1378-1386. doi:10.1111/j.15264610.2009.01486.x

136. Radat, F. Stress et migraine [Stress and migraine]. Rev. Neurol (Paris) 2013, 169(5), 406-412. doi:10.1016/j.neurol.2012.11.008

137. Davalos, D.; Grutzendler, J.; Yang, G.; Kim, J.V.; Zuo, Y.; Jung, S.; Littman, D.R.; Dustin, M.L.; Gan, W.B. ATP mediates rapid microglial response to local brain injury in vivo. Nat. Neurosci. 2005, 8(6), 752-758. doi:10.1038/nn1472

138. Hanisch, U.K.; Kettenmann, H. Microglia: active sensor and versatile effector cells in the normal and pathologic brain. Nat. Neurosci. 2007, 10(11), 1387-1394. doi:10.1038/nn1997

139. Colton, C.A.; Gilbert, D.L. Production of superoxide anions by a CNS macrophage, the microglia. FEBS Lett. 1987, 223(2), 284-288. doi:10.1016/0014-5793(87)80305-8 
140. de Vries, H.E.; Blom-Roosemalen, M.C.; van Oosten, M.; de Boer, A.G.; van Berkel, T.J.; Breimer, D.D.; Kuiper, J. The influence of cytokines on the integrity of the blood-brain barrier in vitro. J. Neuroimmunol. 1996, 64(1), 37-43. doi:10.1016/0165-5728(95)00148-4

141. Färber, K.; Kettenmann, H. Physiology of microglial cells. Brain Res. Brain Res. Rev. 2005, 48(2), 133-143. doi:10.1016/j.brainresrev.2004.12.003

142. Pannasch, U.; Färber, K.; Nolte, C.; Blonski, M.; Yan Chiu, S.; Messing, A.; Kettenmann, H. The potassium channels Kv1.5 and Kv1.3 modulate distinct functions of microglia. Mol. Cell Neurosci. 2006, 33(4), 401-411. doi:10.1016/j.mcn.2006.08.009

143. Pocock, J.M.; Kettenmann, H. Neurotransmitter receptors on microglia. Trends Neurosci. 2007, $30(10)$, 527-535. doi:10.1016/j.tins.2007.07.007

144. Taylor, D.L.; Jones, F.; Kubota, E.S.; Pocock, J.M. Stimulation of microglial metabotropic glutamate receptor mGlu2 triggers tumor necrosis factor alpha-induced neurotoxicity in concert with microglial-derived Fas ligand. J. Neurosci. 2005, 25(11), 2952-2964. doi:10.1523/JNEUROSCI.4456-04.2005

145. Biber, K.; Neumann, H.; Inoue, K.; Boddeke, H.W. Neuronal 'On' and 'Off' signals control microglia. Trends Neurosci. 2007, 30(11), 596-602. doi:10.1016/j.tins.2007.08.007

146. Kоуаmа, Y. Endothelin ETв Receptor-Mediated Astrocytic Activation: Pathological Roles in Brain Disorders. Int. J. Mol. Sci. 2021, 22, 4333. https://doi.org/10.3390/ijms22094333

147. Fiebich, B.L.; Schleicher, S.; Butcher, R.D.; Craig, A.; Lieb, K. The neuropeptide substance P activates p38 mitogenactivated protein kinase resulting in IL-6 expression independently from NF-kappa B. J. Immunol. 2000, 165(10), 56065611. doi:10.4049/jimmunol.165.10.5606

148. Lin, R.C. Reactive astrocytes express substance-P immunoreactivity in the adult forebrain after injury. Neuroreport 1995, 7(1), 310-312.

149. Carthew, H.L.; Ziebell, J.M.; Vink, R. Substance P-induced changes in cell genesis following diffuse traumatic brain injury. Neuroscience 2012, 214, 78-83. doi:10.1016/j.neuroscience.2012.04.028

150. Bruno, P.P.; Carpino, F.; Carpino, G.; Zicari, A. An overview on immune system and migraine. Eur. Rev. Med. Pharmacol. Sci. 2007, 11(4), 245-248.

151. Turner, M.D.; Nedjai, B.; Hurst, T.; Pennington, D.J. Cytokines and chemokines: At the crossroads of cell signalling and inflammatory disease. Biochim. Biophys. Acta. 2014, 1843(11), 2563-2582. doi:10.1016/j.bbamcr.2014.05.014

152. Edvinsson, L.; Haanes, K.A.; Warfvinge, K. Does inflammation have a role in migraine? Nat. Rev. Neurol. 2019, 15(8), 483-490. doi:10.1038/s41582-019-0216-y

153. Roach, D.R.; Bean, A.G.; Demangel, C.; France, M.P.; Briscoe, H.; Britton, W.J. TNF regulates chemokine induction essential for cell recruitment, granuloma formation, and clearance of mycobacterial infection. J. Immunol. 2002, 168(9), 4620-4627. doi:10.4049/jimmunol.168.9.4620

154. Conti, P.; D'Ovidio, C.; Conti, C.; Gallenga, C.E.; Lauritano, D.; Caraffa, A.; Kritas, S.K.; Ronconi, G. Progression in migraine: Role of mast cells and pro-inflammatory and anti-inflammatory cytokines. Eur. J. Pharmacol. 2019, 844, 87-94. doi:10.1016/j.ejphar.2018.12.004

155. Empl, M.; Sostak, P.; Riedel, M.; Schwarz, M.; Müller, N.; Förderreuther, S.; Straube, A. Decreased sTNF-RI in migraine patients? Cephalalgia 2003, 23(1), 55-58. doi:10.1046/j.1468-2982.2003.00453.x

156. Mueller, L.; Gupta, A.K.; Stein, T.P. Deficiency of tumor necrosis factor alpha in a subclass of menstrual migraineurs. Headache 2001, 41(2), 129-137. doi:10.1046/j.1526-4610.2001.111006129.x

157. Christopherson, K. 2nd; Hromas, R. Chemokine regulation of normal and pathologic immune responses. Stem Cells 2001, 19(5), 388-396. doi:10.1634/stemcells.19-5-388

158. Tsay, H.J.; Liu, H.K.; Kuo, Y.H.; Chiu, C.S.; Liang, C.C.; Chung, C.W.; Chen, C.C.; Chen, Y.P.; Shiao, Y.J. EK100 and Antro-din C Improve Brain Amyloid Pathology in APP/PS1 Transgenic Mice by Promoting Microglial and Perivascular Clearance Pathways. Int. J. Mol. Sci. 2021, 22, 10413. https://doi.org/10.3390/ijms221910413

159. Lam, S.; Hartmann, N.; Benfeitas, R.; Zhang, C.; Arif, M.; Turkez, H.; Uhlén, M.; Englert, C.; Knight, R.; Mardinoglu, A. Systems Analysis Reveals Ageing-Related Perturbations in Retinoids and Sex Hormones in Alzheimer's and Parkinson's Diseases. Biomedicines 2021, 9, 1310. https://doi.org/10.3390/biomedicines9101310

160. Hsu, Y.L.; Hung, H.S.; Tsai, C.W.; Liu, S.P.; Chiang, Y.T.; Kuo, Y.H.; Shyu, W.C.; Lin, S.Z.; Fu, R.H. Peiminine Reduces ARTS-Mediated Degradation of XIAP by Modulating the PINK1/Parkin Pathway to Ameliorate 6-Hydroxydopamine Toxicity and $\alpha$-Synuclein Accumulation in Parkinson's Disease Models In Vivo and In Vitro. Int. J. Mol. Sci. 2021, 22, 10240. https://doi.org/10.3390/ijms221910240

161. Smagin, D.A.; Kovalenko, I.L.; Galyamina, A.G.; Belozertseva, I.V.; Tamkovich, N.V.; Baranov, K.O.; Kudryavtseva, N.N. Chronic Lithium Treatment Affects Anxious Behaviors and the Expression of Serotonergic Genes in Midbrain Raphe Nuclei of Defeated Male Mice. Biomedicines 2021, 9, 1293. https://doi.org/10.3390/biomedicines9101293

162. Bezerra, F.; Niemietz, C.; Schmidt, H.H.J.; Zibert, A.; Guo, S.; Monia, B.P.; Gonçalves, P.; Saraiva, M.J.; Almeida, M.R. In Vitro and In Vivo Effects of SerpinA1 on the Modulation of Transthyretin Proteolysis. Int. J. Mol. Sci. 2021, $22,9488$. https://doi.org/10.3390/ijms22179488

163. Lee, G.A.; Lin, Y.K.; Lai, J.H.; Lo, Y.C.; Yang, Y.S.H.; Ye, S.Y.; Lee, C.J.; Wang, C.C.; Chiang, Y.H.; Tseng, S.H. Maternal Immune Activation Causes Social Behavior Deficits and Hypomyelination in Male Rat Offspring with an Autism-Like Microbiota Profile. Brain Sci. 2021, 11, 1085. doi:10.3390/brainsci11081085 
164. Garro-Martínez, E.; Fullana, M.N.; Florensa-Zanuy, E.; Senserrich, J.; Paz, V.; Ruiz-Bronchal, E.; Adell, A.; Castro, E.; Díaz, Á.; Pazos, Á.; Bortolozzi, A.; Pilar-Cuéllar, F. mTOR Knockdown in the Infralimbic Cortex Evokes A DepressiveLike State in Mouse. Int. J. Mol. Sci. 2021, 22, 8671. doi:10.3390/ijms22168671

165. Santana-Santana, M.; Bayascas, J.R.; Giménez-Llort, L. Sex-Dependent Signatures, Time Frames and Longitudinal FineTuning of the Marble Burying Test in Normal and AD-Pathological Aging Mice. Biomedicines 2021, $9,994$. doi:10.3390/biomedicines9080994

166. Abuaish, S.; Al-Otaibi, N.M.; Abujamel, T.S.; Alzahrani, S.A.; Alotaibi, S.M.; AlShawakir, Y.A.; Aabed, K.; El-Ansary, A. Fecal Transplant and Bifidobacterium Treatments Modulate Gut Clostridium Bacteria and Rescue Social Impairment and Hippocampal BDNF Expression in a Rodent Model of Autism. Brain Sci. 2021, 11, 1038. doi:10.3390/brainsci11081038

167. Phebus, L.A.; Johnson, K.W. Dural inflammation model of migraine pain. Curr. Protoc. Neurosci. 2001, Chapter 9, Unit9.1. doi:10.1002/0471142301.ns0901s06

168. Andreou, A.P.; Summ, O.; Charbit, A.R.; Romero-Reyes, M.; Goadsby, P.J. Animal models of headache: from bedside to bench and back to bedside. Expert Rev. Neurother. 2010, 10(3), 389-411. doi:10.1586/ern.10.16

169. Lukács, M.; Haanes, K.A.; Majláth, Z.; Tajti, J.; Vécsei, L.; Warfvinge, K.; Edvinsson, L. Dural administration of inflammatory soup or Complete Freund's Adjuvant induces activation and inflammatory response in the rat trigeminal ganglion. J. Headache Pain 2015, 16, 564. doi:10.1186/s10194-015-0564-y

170. Ebersberger, A.; Ringkamp, M.; Reeh, P.W.; Handwerker, H.O. Recordings from brain stem neurons responding to chemical stimulation of the subarachnoid space. J. Neurophysiol. 1997, 77(6), 3122-3133. doi:10.1152/jn.1997.77.6.3122

171. Laborc, K.F.; Spekker, E.; Bohár, Z.; Szűcs, M.; Nagy-Grócz, G.; Fejes-Szabó, A.; Vécsei, L.; Párdutz, Á. Trigeminal activation patterns evoked by chemical stimulation of the dura mater in rats. J. Headache Pain 2020, $21(1), 101$. doi:10.1186/s10194-020-01169-4

172. Spekker, E.; Laborc, K.F.; Bohár, Z.; Nagy-Grócz, G.; Fejes-Szabó, A.; Szűcs, M.; Vécsei, L.; Párdutz, Á. Effect of dural inflammatory soup application on activation and sensitization markers in the caudal trigeminal nucleus of the rat and the modulatory effects of sumatriptan and kynurenic acid. J. Headache Pain 2021, 22(1), 17. doi:10.1186/s10194-021-012293

173. Wieseler, J.; Ellis, A.; McFadden, A.; Stone, K.; Brown, K.; Cady, S.; Bastos, L.F.; Sprunger, D.; Rezvani, N.; Johnson, K.; Rice, K.C.; Maier, S.F.; Watkins, L.R. Supradural inflammatory soup in awake and freely moving rats induces facial allodynia that is blocked by putative immune modulators. Brain Res. 2017, 1664, 87-94. doi:10.1016/j.brainres.2017.03.011

174. Oshinsky, M.L.; Gomonchareonsiri, S. Episodic dural stimulation in awake rats: a model for recurrent headache. Headache 2007, 47(7), 1026-1036. doi:10.1111/j.1526-4610.2007.00871.x

175. Melo-Carrillo, A.; Lopez-Avila, A. A chronic animal model of migraine, induced by repeated meningeal nociception, characterized by a behavioral and pharmacological approach. Cephalalgia 2013, 33(13), 1096-1105. doi:10.1177/0333102413486320

176. Ferrari, M.D. Migraine. Lancet 1998, 351(9108), 1043-1051. doi:10.1016/S0140-6736(97)11370-8

177. Malick, A.; Jakubowski, M.; Elmquist, J.K.; Saper, C.B.; Burstein, R. A neurohistochemical blueprint for pain-induced loss of appetite [published correction appears in Proc. Natl. Acad. Sci. U S A 2001, 98(24), 14186]. Proc. Natl. Acad. Sci. U S A 2001, 98(17), 9930-9935. doi:10.1073/pnas.171616898

178. Wieseler, J.; Ellis, A.; Sprunger, D.; Brown, K.; McFadden, A.; Mahoney, J.; Rezvani, N.; Maier, S.F.; Watkins, L.R. A novel method for modeling facial allodynia associated with migraine in awake and freely moving rats. J. Neurosci. Methods 2010, 185(2), 236-245. doi:10.1016/j.jneumeth.2009.10.006

179. Chen, N.; Su, W.; Cui, S.H.; Guo, J.; Duan, J.C.; Li, H.X.; He, L. A novel large animal model of recurrent migraine established by repeated administration of inflammatory soup into the dura mater of the rhesus monkey. Neural Regen. Res. 2019, 14(1), 100-106. doi:10.4103/1673-5374.243715

180. Saxena, P.R.; De Vries, P.; Villalón, C.M. 5-HT1-like receptors: a time to bid goodbye. Trends Pharmacol. Sci. 1998, 19(8), 311-316. doi:10.1016/s0165-6147(98)01228-0

181. Buzzi, M.G.; Moskowitz, M.A. The antimigraine drug, sumatriptan (GR43175), selectively blocks neurogenic plasma extravasation from blood vessels in dura mater. Br. J. Pharmacol. 1990, 99(1), 202-206. doi:10.1111/j.14765381.1990.tb14679.x

182. Cutrer, F.M.; Yu, X.J.; Ayata, G.; Moskowitz, M.A.; Waeber, C. Effects of PNU-109,291, a selective 5-HT1D receptor agonist, on electrically induced dural plasma extravasation and capsaicin-evoked c-fos immunoreactivity within trigeminal nucleus caudalis. Neuropharmacology 1999, 38(7), 1043-1053. doi:10.1016/s0028-3908(99)00032-5

183. Tanaka, M.; Török, N.; Vécsei, L. Are 5-HT1 receptor agonists effective anti-migraine drugs? Expert Opin. Pharmacother. 2021, 22(10), 1221-1225. doi:10.1080/14656566.2021.1910235

184. Moskowitz, M.A. Neurogenic versus vascular mechanisms of sumatriptan and ergot alkaloids in migraine. Trends Pharmacol. Sci. 1992, 13(8), 307-311. doi:10.1016/0165-6147(92)90097-p

185. Goadsby, P.J.; Lipton, R.B.; Ferrari, M.D. Migraine--current understanding and treatment. N. Engl. J. Med. 2002, 346(4), 257-270. doi:10.1056/NEJMra010917

186. Tso, A.R.; Goadsby, P.J. Anti-CGRP Monoclonal Antibodies: the Next Era of Migraine Prevention? Curr. Treat. Options Neurol. 2017, 19(8), 27. doi:10.1007/s11940-017-0463-4

187. Yuan, H.; Lauritsen, C.G.; Kaiser, E.A.; Silberstein, S.D. CGRP Monoclonal Antibodies for Migraine: Rationale and Progress. BioDrugs 2017, 31(6), 487-501. doi:10.1007/s40259-017-0250-5 
188. Negro, A.; Martelletti, P. Novel synthetic treatment options for migraine. Expert Opin. Pharmacother. 2021, 22(7), 907922. doi: 10.1080/14656566.2020.1862793

189. Olesen, J.; Diener, H.C.; Husstedt, I.W.; Goadsby, P.J.; Hall, D.; Meier, U.; Pollentier, S.; Lesko, L.M. Calcitonin generelated peptide receptor antagonist BIBN 4096 BS for the acute treatment of migraine. N. Engl. J. Med. 2004, 350(11), 1104-1110. doi:10.1056/NEJMoa030505

190. Peroutka, S.J. Neurogenic inflammation and migraine: implications for the therapeutics. Mol. Interv. 2005, 5(5), 304-311. doi:10.1124/mi.5.5.10

191. Zimmer, A.; Zimmer, A.M.; Baffi, J.; Usdin, T.; Reynolds, K.; König, M.; Palkovits, M.; Mezey, E. Hypoalgesia in mice with a targeted deletion of the tachykinin 1 gene. Proc. Natl. Acad. Sci. U S A 1998, 95(5), 2630-2635. doi:10.1073/pnas.95.5.2630

192. Cao, Y.Q.; Mantyh, P.W.; Carlson, E.J.; Gillespie, A.M.; Epstein, C.J.; Basbaum, A.I. Primary afferent tachykinins are required to experience moderate to intense pain. Nature 1998, 392(6674), 390-394. doi:10.1038/32897

193. Lee, W.S.; Moussaoui, S.M.; Moskowitz, M.A. Blockade by oral or parenteral RPR 100893 (a non-peptide NK1 receptor antagonist) of neurogenic plasma protein extravasation within guinea-pig dura mater and conjunctiva. Br. J. Pharmacol. 1994, 112(3), 920-924. doi:10.1111/j.1476-5381.1994.tb13168.x

194. Goldstein, D.J.; Wang, O.; Saper, J.R.; Stoltz, R.; Silberstein, S.D.; Mathew, N.T. Ineffectiveness of neurokinin-1 antagonist in acute migraine: a crossover study. Cephalalgia 1997, 17(7), 785-790. doi:10.1046/j.1468-2982.1997.1707785.x

195. Goldstein, D.J.; Offen, W.W.; Klein, E.G.; Phebus, L.A.; Hipskind, P.; Johnson, K.W.; Ryan, R.E. Jr. Lanepitant, an NK-1 antagonist, in migraine prevention. Cephalalgia 2001, 21(2), 102-106. doi:10.1046/j.1468-2982.2001.00161.x

196. Herrstedt, J.; Muss, H.B.; Warr, D.G.; Hesketh, P.J.; Eisenberg, P.D.; Raftopoulos, H.; Grunberg, S.M.; Gabriel, M.; Rodgers, A.; Hustad, C.M.; Horgan, K.J.; Skobieranda, F. Efficacy and tolerability of aprepitant for the prevention of chemotherapy-induced nausea and emesis over multiple cycles of moderately emetogenic chemotherapy [published correction appears in Cancer 2006, 106(7), 1641]. Cancer 2005, 104(7), 1548-1555. doi:10.1002/cncr.21343

197. Jara-Oseguera, A.; Simon, S.A.; Rosenbaum, T. TRPV1: on the road to pain relief. Curr. Mol. Pharmacol. 2008, 1(3), 255269. doi:10.2174/1874467210801030255

198. Leimuranta, P.; Khiroug, L.; Giniatullin, R. Emerging Role of (Endo)Cannabinoids in Migraine. Front. Pharmacol. 2018, 9, 420. doi:10.3389/fphar.2018.00420

199. Tsou, K.; Brown, S.; Sañudo-Peña, M.C.; Mackie, K.; Walker, J.M. Immunohistochemical distribution of cannabinoid CB1 receptors in the rat central nervous system. Neuroscience 1998, 83(2), 393-411. doi:10.1016/s0306-4522(97)00436-3

200. Matsuda, L.A.; Lolait, S.J.; Brownstein, M.J.; Young, A.C.; Bonner, T.I. Structure of a cannabinoid receptor and functional expression of the cloned cDNA. Nature 1990, 346(6284), 561-564. doi:10.1038/346561a0

201. Russo, E.B. Clinical endocannabinoid deficiency (CECD): can this concept explain therapeutic benefits of cannabis in migraine, fibromyalgia, irritable bowel syndrome and other treatment-resistant conditions? Neuro. Endocrinol. Lett. 2004, 25(1-2), 31-39.

202. Greco, R.; Demartini, C.; Zanaboni, A.M.; Piomelli, D.; Tassorelli, C. Endocannabinoid System and Migraine Pain: An Update. Front. Neurosci. 2018, 12, 172. doi:10.3389/fnins.2018.00172

203. Cupini, L.M.; Bari, M.; Battista, N.; Argiró, G.; Finazzi-Agró, A.; Calabresi, P.; Maccarrone, M. Biochemical changes in endocannabinoid system are expressed in platelets of female but not male migraineurs. Cephalalgia 2006, 26(3), $277-281$. doi:10.1111/j.1468-2982.2005.01031.x

204. Akerman, S.; Kaube, H.; Goadsby, P.J. Anandamide is able to inhibit trigeminal neurons using an in vivo model of trigeminovascular-mediated nociception. J. Pharmacol. Exp. Ther. 2004, 309(1), 56-63. doi:10.1124/jpet.103.059808

205. Nagy-Grócz, G.; Bohár, Z.; Fejes-Szabó, A.; Laborc, K.F.; Spekker, E.; Tar, L.; Vécsei, L.; Párdutz, Á. Nitroglycerin increases serotonin transporter expression in rat spinal cord but anandamide modulated this effect. J. Chem. Neuroanat. 2017, 85, 13-20. doi: 10.1016/j.jchemneu.2017.06.002

206. Tajti, J.; Tuka, B.; Botz, B.; Helyes, Z.; Vécsei, L. Role of pituitary adenylate cyclase-activating polypeptide in nociception and migraine. CNS Neurol. Disord. Drug Targets 2015, 14(4), 540-553. doi:10.2174/1871527314666150429114234

207. Rubio-Beltrán, E.; Correnti, E.; Deen, M. PACAP38 and PAC1 receptor blockade: a new target for headache? J. Headache Pain 2018, 19(1), 64. doi:10.1186/s10194-018-0893-8

208. Tanaka, M.; Vécsei, L. Monitoring the kynurenine system: Concentrations, ratios or what else? Adv. Clin. Exp. Med. 2021, 30(8), 775-778. doi:10.17219/acem/139572

209. Török, N.; Tanaka, M.; Vécsei, L. Searching for Peripheral Biomarkers in Neurodegenerative Diseases: The TryptophanKynurenine Metabolic Pathway. Int. J. Mol. Sci. 2020, 21, 9338. doi:10.3390/ijms21249338

210. Liao, C.; de Molliens, M.P.; Schneebeli, S.T.; Brewer, M.; Song, G.; Chatenet, D.; Braas, K.M.; May, V.; Li, J. Targeting the PAC1 Receptor for Neurological and Metabolic Disorders. Curr. Top. Med. Chem. 2019, 19(16), $1399-1417$. doi:10.2174/1568026619666190709092647

211. Fejes, A.; Párdutz, Á.; Toldi, J.; Vécsei, L. Kynurenine metabolites and migraine: experimental studies and therapeutic perspectives. Curr. Neuropharmacol. 2011, 9(2), 376-387. doi:10.2174/157015911795596621

212. Tajti, J.; Majlath, Z.; Szok, D.; Csati, A.; Toldi, J.; Fülöp, F.; Vécsei, L. Novel kynurenic acid analogues in the treatment of migraine and neurodegenerative disorders: preclinical studies and pharmaceutical design. Curr. Pharm. Des. 2015, 21(17), 2250-2258. doi:10.2174/1381612821666150105163055

213. Tanaka, M.; Toldi, J.; Vécsei, L. Exploring the Etiological Links behind Neurodegenerative Diseases: Inflammatory Cytokines and Bioactive Kynurenines. Int. J. Mol. Sci. 2020, 21, 2431. https://doi.org/10.3390/ijms21072431 
214. Tanaka, M.; Tóth, F.; Polyák, H.; Szabó, Á.; Mándi, Y.; Vécsei, L. Immune Influencers in Action: Metabolites and Enzymes of the Tryptophan-Kynurenine Metabolic Pathway. Biomedicines 2021, 9, 734 . doi:10.3390/biomedicines9070734

215. Tanaka, M.; Török, N.; Tóth, F.; Szabó, Á.; Vécsei, L. Co-Players in Chronic Pain: Neuroinflammation and the Tryptophan-Kynurenine Metabolic Pathway. Biomedicines 2021, 9, 897. https://doi.org/10.3390/biomedicines9080897

216. Curto, M.; Lionetto, L.; Negro, A.; Capi, M.; Fazio, F.; Giamberardino, M.A.; Simmaco, M.; Nicoletti, F.; Martelletti, P. Altered kynurenine pathway metabolites in serum of chronic migraine patients. J. Headache Pain 2015, $17,47$. https://doi.org/10.1186/s10194-016-0638-5

217. Sarchielli, P.; Di Filippo, M.; Nardi, K.; Calabresi, P. Sensitization, glutamate, and the link between migraine and fibromyalgia. Curr. Pain Headache Rep. 2007, 11(5), 343-351. https://doi.org/10.1007/s11916-007-0216-2

218. Nagy-Grócz, G.; Laborc, K.F.; Veres, G.; Bajtai, A.; Bohár, Z.; Zádori, D.; Fejes-Szabó, A.; Spekker, E.; Vécsei, L.; Párdutz, Á. The Effect of Systemic Nitroglycerin Administration on the Kynurenine Pathway in the Rat. Front. Neurol. 2017, 14(8), 278. doi: 10.3389/fneur.2017.00278

219. Mándi, Y.; Vécsei, L. The kynurenine system and immunoregulation. J. Neural trans. 2012, 119(2), 197-209. https://doi.org/10.1007/s00702-011-0681-y

220. Lukács, M.; Tajti, J.; Fülöp, F.; Toldi, J.; Edvinsson, L.; Vécsei, L. Migraine, Neurogenic Inflammation, Drug Development - Pharmacochemical Aspects. Curr. Med. Chem. 2017, 24(33), $3649-3665$. doi:10.2174/0929867324666170712163437

221. Jovanovic, F.; Candido, K.D.; Knezevic, N.N. The Role of the Kynurenine Signaling Pathway in Different Chronic Pain Conditions and Potential Use of Therapeutic Agents. Int. J. Mol. Sci. 2020, 21, 6045. doi: 10.3390/ijms21176045

222. Karakurum Göksel, B. The Use of Complementary and Alternative Medicine in Patients with Migraine. Noro. Psikiyatri Arsivi 2013, 50(Suppl 1), S41-S46. doi:10.4274/npa.y6809 